\title{
JV TASK 77 - HEALTH IMPLICATIONS OF MERCURY-SELENIUM INTERACTIONS
}

\author{
Final Report \\ (for the period of July 1, 2004, through June 30, 2007) \\ Submitted to: \\ AAD Document Control \\ U.S. Department of Energy \\ National Energy Technology Laboratory \\ PO Box 10940, MS 921-107 \\ Pittsburgh, PA 15236-0940 \\ Cooperative Agreement No.: DE-FC26-98FT40321 \\ Project Manager: Robie Lewis
}

Prepared by:

Nicholas V.C. Ralston

Laura J. Raymond

Energy \& Environmental Research Center

University of North Dakota

15 North 23rd Street, Stop 9018

Grand Forks, North Dakota 58202-9018 


\section{DISCLAIMER}

This report was prepared as an account of work sponsored by an agency of the United States Government. Neither the United States Government, nor any agency thereof, nor any of their employees makes any warranty, express or implied, or assumes any legal liability or responsibility for the accuracy, completeness, or usefulness of any information, apparatus, product, or process disclosed or represents that its use would not infringe privately owned rights. Reference herein to any specific commercial product, process, or service by trade name, trademark, manufacturer, or otherwise does not necessarily constitute or imply its endorsement, recommendation, or favoring by the United States Government or any agency thereof. The views and opinions of authors expressed herein do not necessarily state or reflect those of the United States Government or any agency thereof.

This report is available to the public from the National Technical Information Service, U.S. Department of Commerce, 5285 Port Royal Road, Springfield, VA 22161; phone orders accepted at (703) 487-4650.

\section{EERC DISCLAIMER}

LEGAL NOTICE This research report was prepared by the Energy \& Environmental Research Center (EERC), an agency of the University of North Dakota, as an account of work sponsored by the U.S. Department of Energy National Energy Technology Laboratory. Because of the research nature of the work performed, neither the EERC nor any of its employees makes any warranty, express or implied, or assumes any legal liability or responsibility for the accuracy, completeness, or usefulness of any information, apparatus, product, or process disclosed or represents that its use would not infringe privately owned rights. Reference herein to any specific commercial product, process, or service by trade name, trademark, manufacturer, or otherwise does not necessarily constitute or imply its endorsement or recommendation by the EERC. 
JV TASK 77-HEALTH IMPLICATIONS OF MERCURY-SELENIUM INTERACTIONS

\begin{abstract}
Exposure to mercury $(\mathrm{Hg})$ commonly results from eating fish containing bioaccumulated methylmercury (MeHg). However, conflicting observations and conclusions have arisen from the ongoing human studies of $\mathrm{MeHg}$ exposure from fish consumption. Resolving these uncertainties has important implications for human health since significant nutritional benefits will be lost if fish consumption is needlessly avoided. Selenium (Se), an important nutrient that is abundant in ocean fish, has a potent protective effect against $\mathrm{Hg}$ toxicity. This protective effect was thought to be due to the high binding affinities between $\mathrm{Hg}$ and Se resulting in Se sequestration of $\mathrm{Hg}$ to prevent its harmful effects. However, it is imperative to consider the opposing effect of $\mathrm{Hg}$ on Se physiology. Crucial proteins that require Se normally protect the brain and hormone-producing glands from oxidative damage. $\mathrm{MeHg}$ is able to cross all biological barriers and enter cells in these tissues, where its high Se affinity results in Se sequestration. Sequestration in association with $\mathrm{Hg}$ prevents Se from participating in proteins that perform essential antioxidant activities. Supplemental dietary Se is able to replace Se sequestered by $\mathrm{Hg}$ and maintain normal antioxidant protection of brain and glands. The goal of this research project was to assess the potency of normal dietary levels of $\mathrm{Se}$ in protection against $\mathrm{MeHg}$ toxicity. Results from this project indicate that $\mathrm{MeHg}$ toxicity is only evident in situations resulting in $\mathrm{Hg}$ occurring in high molar excess of Se. Additionally, the common method of MeHg risk assessments using measurements of toenail and blood levels of $\mathrm{Hg}$ was shown to provide an accurate reflection of $\mathrm{Hg}$ exposure but did not accurately indicate risk of toxicity resulting from that exposure. Instead, $\mathrm{Hg}$ :Se molar ratios are proposed as a superior means of assessing risks associated with $\mathrm{MeHg}$ exposure.
\end{abstract}




\section{TABLE OF CONTENTS}

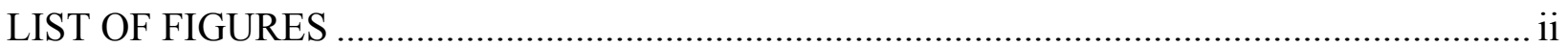

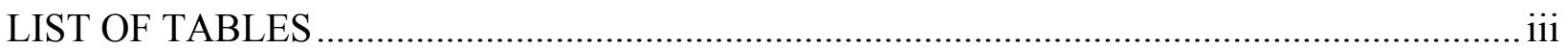

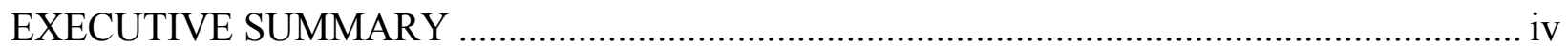

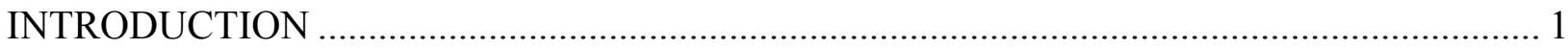

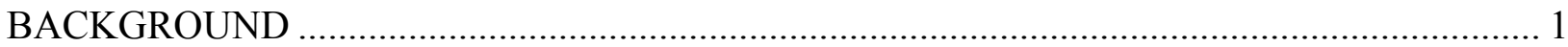

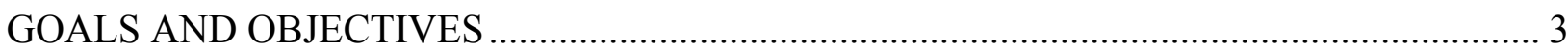

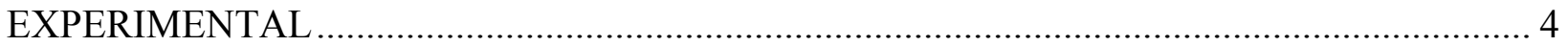

Task 1 - Accumulation, Retention, and Distribution of Selenium and Methylmercury....... 4

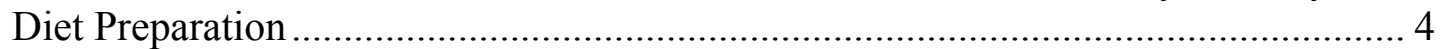

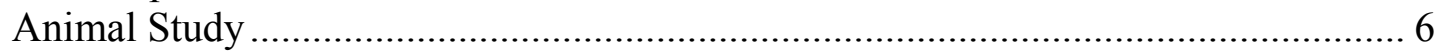

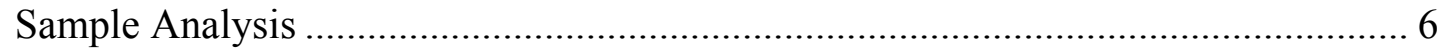

Task 2 - MeHg Binding Affinities to Thio vs. Selenomolecules ………………………..... 7

Task 3 - Determination of Biochemical Threshold of Methylmercury Effects.................... 7

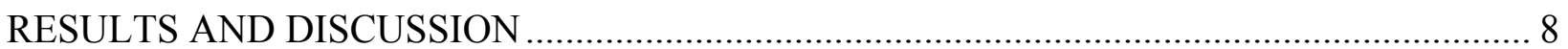

Task 1 - Accumulation and Distribution of Selenium and Methylmercury ......................... 8

Effects of Dietary MeHg and Se on Growth ........................................................ 8

Effects of Dietary MeHg and Se on Elemental Distributions in Kidney..................... 8

Effects of Dietary MeHg and Se on Elemental Distributions in Liver...................... 10

Effects of Dietary MeHg and Se on Elemental Distributions in Testes ..................... 10

Effects of Dietary MeHg and Se on Elemental Distributions in Pituitary.................. 12

Effects of Dietary MeHg and Se on Elemental Distributions in Brain...................... 13

Effects of Dietary MeHg and Se on Elemental Accumulation in Blood................... 13

Effects of Dietary MeHg and Se on Elemental Accumulation in Toenails............... 14

Task 2 - In Vitro Examination of Direct Interactions between MeHg and Se ................... 15

Task 3 - Determination of Biochemical Threshold of MeHg Effects ................................ 16

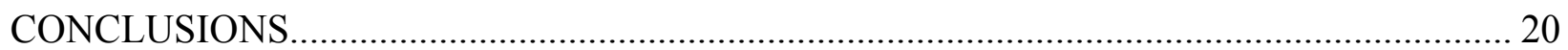

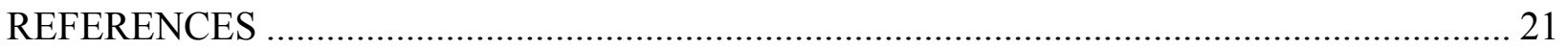




\section{LIST OF FIGURES}

1 Overview of selenoenzyme synthesis (A) and the hypothesized mechanism of

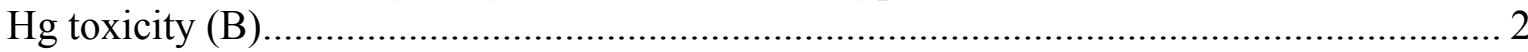

2 Growth of rats fed diets containing graduated quantities of $\mathrm{MeHg}$ and $\mathrm{Se}$......................... 9

3 Se K-edge XANES data for HgSe and beluga (H2) and pygmy sperm whale (H3) liver .. 16

$4 \quad$ POINT models of dietary treatment effects on bioavailability of Se ................................. 17

$5 \quad$ POINT model of effects of dietary treatment on Se bioavailability in rats......................... 18 


\section{LIST OF TABLES}

1 Modified Mineral Mix and Composition of AIN-93G Torula Yeast-Based Diets .............. 5

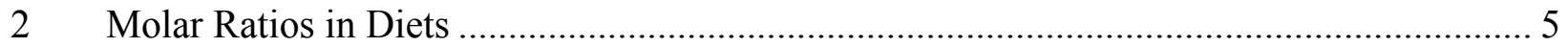

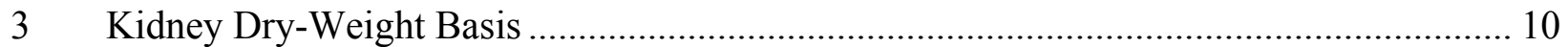

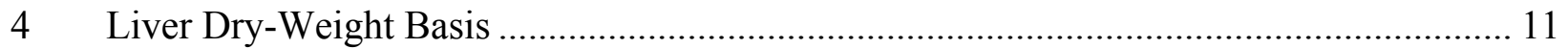

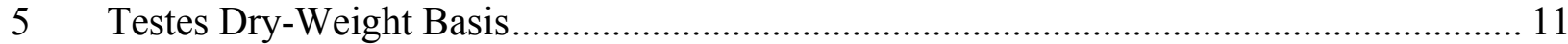

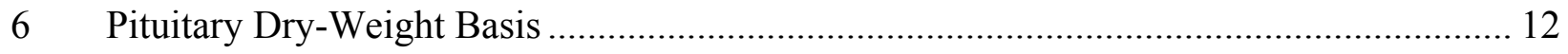

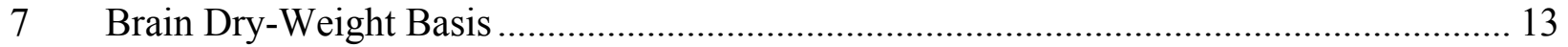

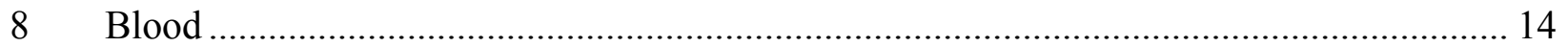

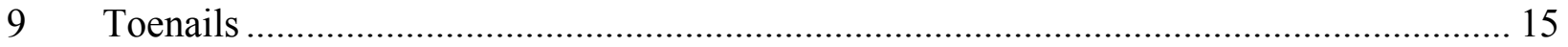

10 Correlations Between Indices and Observed Toxicity ................................................. 19 


\section{JV TASK 77 - HEALTH IMPLICATIONS OF MERCURY-SELENIUM INTERACTIONS}

\section{EXECUTIVE SUMMARY}

Mercury $(\mathrm{Hg})$ contamination is widespread, resulting from its use in many products and its emission from combustion systems. The current level of understanding of the complex interplay of $\mathrm{Hg}$ emission, transport, deposition, and recycling of different forms of $\mathrm{Hg}$ does not allow modelers to correlate particular atmospheric emission sources with human exposure. Therefore, regulatory policies assume sensitivity to $\mathrm{Hg}$ is essentially equivalent across the globe, but research indicates this is not true. Selenium (Se), an essential nutrient for many physiological processes, is beneficial in protecting against $\mathrm{Hg}$ exposure. Studies using animal models have established that Se deficiency increases vulnerability to $\mathrm{Hg}$ toxicity while enhanced dietary $\mathrm{Se}$ status is protective. However, the biochemical mechanism for Se's protective effect against $\mathrm{Hg}$ remains unclear. The influences $\mathrm{Hg}$ and $\mathrm{Se}$ have upon one another may share a common basis in the exceedingly high binding affinity between these elements. Although Se influences Hg's effects in the body, it is imperative to consider the opposing effect of $\mathrm{Hg}$ on Se physiology. This vital aspect is key to understanding $\mathrm{Hg}$ toxicity, yet it has been seriously overlooked. Alarmingly, Hg not only has the ability to cross the placental and blood-brain barrier, but its high affinity for Se enables it to specifically sequester Se in the brain and endocrine tissues, consequently impairing neurobehavioral development, brain neurotransmitter activities, thyroid hormone homeostasis, antioxidant mechanisms, immunity, growth, and development.

Therefore, in order to understand how $\mathrm{Hg}$ fundamentally alters human biology and fetal development and assess its true exposure risk, our long-term goal is to determine the biochemical mechanism of $\mathrm{MeHg}$ toxicity and extent of Se's involvement. It is our central hypothesis that $\mathrm{Hg}$ toxicity is the result of $\mathrm{Hg}$ 's ability to sequester intracellular inorganic Se and inhibit the formation of essential selenoenzymes in the central nervous system, whereas toxicity will not occur when Se status extends this threshold.

The objectives of this project were to assess the biochemical interactions between $\mathrm{Hg}$ and Se through studies uniquely designed to reflect human patterns of $\mathrm{MeHg}$ exposure accompanied by various dietary levels of Se. To meet this objective, three tasks were performed :1) assess the mutual influences of $\mathrm{Hg}$ and $\mathrm{Se}$ on one another's uptake, retention, and distribution in a controlled laboratory animal study utilizing systematically graduated dietary exposures to each element; 2) examine direct interactions between $\mathrm{Hg}$ and Se by measuring bound $\mathrm{Hg}-\mathrm{Se}$ ratios in tissue samples using x-ray absorption fine structure (XAFS) analysis; and 3) further the development of a computational method of interpreting and evaluating research data by using the Physiologically Oriented Integration of Nutrients and Toxins (POINT) model reflecting the influence of $\mathrm{MeHg}$ on Se availability in various tissue compartments.

The overall conclusion of this project indicates that $\mathrm{Hg}$ toxicity is only evident in situations resulting in molar excess of $\mathrm{Hg}$ :Se ratios. Additionally, the common method of risk assessments using measurements of toenail and blood levels of $\mathrm{Hg}$ was shown to provide an accurate reflection of $\mathrm{Hg}$ exposure but did not indicate toxicity risk. 


\section{JV TASK 77 - HEALTH IMPLICATIONS OF MERCURY-SELENIUM INTERACTIONS}

\section{INTRODUCTION}

Proper evaluation of selenium (Se)-dependent protective effects against risk often associated with methylmercury ( $\mathrm{MeHg}$ ) exposure is a major issue in seafood safety. However, there is still a critical gap in this aspect of the knowledge base regarding the magnitude of these effects. The data generated from this project support the premise that simply defining the amount of $\mathrm{Hg}$ present in food provides an inaccurate indication of the risk associated with its consumption. This project was designed to assess the significance of Se's protective effect from dietary $\mathrm{Hg}$ exposure at realistic and human consumption levels. This issue is extremely important because the health risks from dietary $\mathrm{MeHg}$ consumption are dependent on relative amount of $\mathrm{Hg}$ and Se present in foods. Likewise, the Se present in many foods, including fish, is protective against $\mathrm{Hg}$ exposure, thus minimizing or eliminating the potential risk from its consumption.

\section{BACKGROUND}

Exposure to $\mathrm{Hg}$ commonly results from eating fish containing $\mathrm{MeHg}$ that has accumulated in the food chain. Yet, conflicting observations and conclusions have arisen from the ongoing studies of children neonatally exposed to $\mathrm{Hg}$ from maternal fish and whale consumption. Major studies in the New Zealand and Faroe Islands populations report neurological defects accompany $\mathrm{MeHg}$ exposure, but no adverse effects were indicated in the Seychelle Islands population, even though their average $\mathrm{MeHg}$ exposure is greater. In the United Kingdom study, no harm was associated with increasing fish consumption, but avoiding fish consumption was associated with harm. However, Se, an important nutrient present in many foods including fish, has a potent protective effect against $\mathrm{Hg}$ toxicity. Although Se influences Hg's effects in the body, it is imperative to consider the opposing effect of $\mathrm{Hg}$ on Se physiology. This vital aspect is key to understanding $\mathrm{Hg}$ toxicity and may explain the differences noted in these studies, yet it has been seriously overlooked.

Se's protective effects against $\mathrm{MeHg}$ is attributed to the high binding affinities between inorganic $\mathrm{Hg}\left(\mathrm{Hg}^{2+}\right)$ and the inorganic forms of Se that are continuously formed within all living animal cells. Although $\mathrm{MeHg}$ is the form that is initially consumed, $\mathrm{Hg}^{2+}$ is released from $\mathrm{MeHg}$ inside cells following demethylation (by lyase enzymes). When the toxicity of $\mathrm{MeHg}$ is considered, it is important to understand the unrivaled high binding affinities of $\mathrm{MeHg}$ and $\mathrm{Hg}^{2+}$ with inorganic forms of Se that arise within cells during every cycle of selenoenzyme synthesis. The affinity constant for $\mathrm{Hg}$ and the $\mathrm{Se}$ in selenocysteine (SeCys), the amino acid present at the active sites of all Se-dependent enzymes, is $\sim 10^{22}$, and the free selenides that form during each cycle of SeCys synthesis have an exceptionally high affinity constant for $\mathrm{Hg}: 10^{45}$ (Dyrssen et al., 1991). Since total $\mathrm{Se}$ is usually in great excess of $\mathrm{Hg}$, cells can maintain their normal rates of selenoenzyme synthesis. However, if the amount of $\mathrm{MeHg}$ incorporated in a cell exceeds the 
available Se, normal selenoenzyme synthesis is vulnerable. Once Se is sequestered by $\mathrm{Hg}$, it is unavailable for selenoenzyme synthesis. Therefore, the protective effect of Se may be due to ensuring adequate levels of Se are available to offset the amount sequestered by $\mathrm{Hg}$ (Figure 1).

Ironically, until approximately 45 years ago, Se was known only as a poison itself. It is now known that Se is essential for the normal function of 20-30 enzymes in the body and that two of the 22 primary amino acids normally present in all cells of all animals (selenomethionine and SeCys) are distinguished by the presence of Se (Behne et al., 2000). Selenomethionine is biochemically equivalent to methionine and is chiefly regarded as an unregulated storage compartment for Se. In contrast, SeCys is tightly regulated and specifically incorporated into proteins (selenoproteins) that perform numerous biological functions. The Se of SeCys is the primary chemical participant that performs the actual biochemical function of these enzymes and is incorporated into the polypeptide chain by using UGA as the encoding codon (Burk and Hill, 1993). Remarkably, SeCys is the only amino acid that must be degraded and reformed during each cycle of selenoprotein synthesis. This process releases selenide from SeCys during the degradation step, rendering it vulnerable to $\mathrm{Hg}$ sequestration.

Se is essential for the normal physiological function of many systems of the body, and Se deficiency can have adverse effects on these systems. Se can act as a growth factor (Ramauge et al., 1996), has powerful antioxidant (Behne et al., 2000) and anticancer (Combs and Lu, 2006) properties, and is essential for normal thyroid hormone homeostasis (Ramauge et al., 1996) and immunity (Roy et al., 1995). Studies indicate Se has important roles in development, reproduction, cardiovascular disease, and mood disorders. The potential role of defects in Se physiology in disease is becoming increasingly apparent. Compromised Se-dependant metabolic processes have been linked to congenital muscular dystrophy, autism, Alzheimer's and Down syndromes, brain tumors, diabetes, liver diseases, and any condition associated with increased

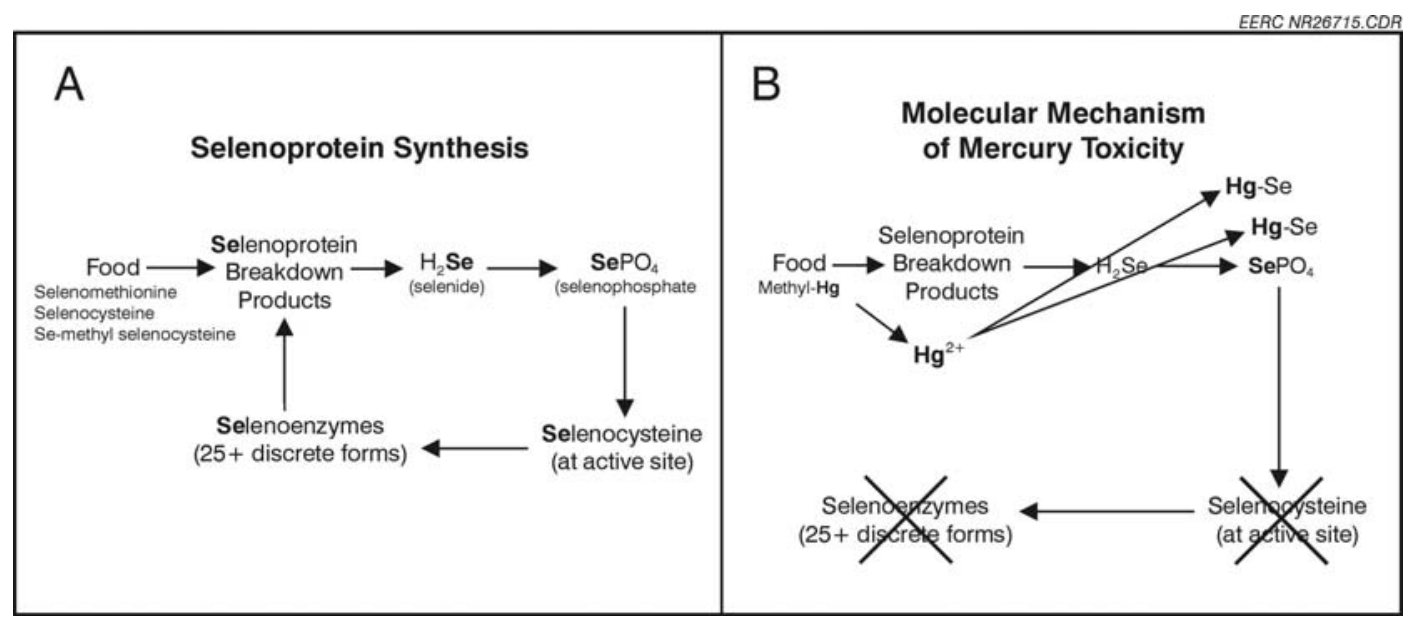

Figure 1. Overview of selenoenzyme synthesis (A) and the hypothesized mechanism of $\mathrm{Hg}$ toxicity (B). The normal cycle of selenoprotein synthesis is depicted on the left. Disruption of this cycle by toxic quantities of $\mathrm{Hg}$ is depicted on the right. Selenide freed during selenoprotein breakdown is available to bind with $\mathrm{Hg}$. Formation of insoluble $\mathrm{Hg}$ selenides reduces the bioavailability of Se for protein synthesis. 
oxidative stress or inflammation such as rheumatoid arthritis, pancreatitis, asthma, and obesity (for reviews see Whanger, 2001; Rayman, 2000; Kohrle et al., 2000).

The importance of Se in the endocrine system is emphasized by the fact that mechanisms have evolved to maintain normal concentrations of Se in these tissues even when there is severe dietary Se deficiency. Se deficiency occurs in experimental animals continuously fed diets that contain negligible amounts of Se. After a period of months, the Se concentrations in peripheral tissues such as liver, skeletal muscle, and blood of these animals become drastically reduced to levels below $1 \%$ of normal. However, their brain tissues retain $60 \%$ of the Se concentration found in control animal brains (Behne et al., 2000). However, Behne and others report their offspring have similarly low Se levels in their peripheral tissues, but maintain $\sim 60 \%$ of normal Se contents in their brains through six generations of continuous feeding of Se-deficient diets.

Although brain Se concentrations in Se-deficient animals have not been reduced to less than $60 \%$ of normal, Hill showed that feeding diets containing less than $0.1 \mathrm{ppm}$ Se to selenoprotein $\mathrm{P}$ knockout mice reduced their brain Se concentrations to $43 \%$ of normal, the lowest brain Se concentration achieved in any experimental animal model (Hill et al., 2003). While rats with brain $\mathrm{Se}$ at $60 \%$ of normal appear asymptomatic, the knockout mice demonstrated pronounced loss of motor coordination. Motor coordination could be restored and brain Se replenished by feeding them diets containing $2 \mathrm{mg} \mathrm{Se} / \mathrm{kg}$ diet. As further evidence demonstrating the importance of Se-dependent physiology, the total disruption of selenoprotein synthesis in mice, achieved by knocking out the selenocysteinyl-tRNA gene, resulted in early embryonic lethality (Bosl et al., 1997).

Consequently, any substance that can enter the brain and disrupt selenoprotein synthesis in these tissues will accomplish what multigenerational Se deficiency cannot. $\mathrm{Hg}$ not only has the ability to cross the placental and blood-brain barrier, but its high Se affinity enables it to specifically sequester the brain's Se by forming insoluble $\mathrm{Hg}$ selenides, consequently impairing Se-dependent enzyme activities required for normal motor function, brain neurotransmitter activities, antioxidant mechanisms, and development.

In order to correctly evaluate risk of $\mathrm{MeHg}$ exposure, it is imperative to determine the threshold of MeHg-dependent toxicity on inhibition of Se physiology. Since the health risk from $\mathrm{MeHg}$ varies in relation to Se intake, clarifying the significance of these $\mathrm{Hg}-\mathrm{Se}$ interactions is essential. Ocean fish is one of the richest sources of dietary Se and is also the main source of $\mathrm{MeHg}$ exposure; therefore, these interactions are especially important concerning fish consumption risks and advisories. Elucidating the extent of Se's protection against $\mathrm{Hg}$ toxicity is vital because research is proving that significant nutritional and developmental benefits are lost when fish consumption is needlessly avoided.

\section{GOALS AND OBJECTIVES}

The goal of this EERC program was to improve the understanding of Hg-Se binding interactions and its involvement in Se-dependent prevention of $\mathrm{MeHg}$ toxicity. The primary objective of this project was to investigate the biochemical mechanism for dietary Se's protective 
effect against $\mathrm{Hg}$ toxicity using the normal range of dietary Se. The activities of this project will enhance the ongoing EERC investigation of $\mathrm{Hg}-\mathrm{Se}$ interaction mechanisms and investigations to determine Se's role in protection against $\mathrm{MeHg}$ toxicity.

The specific objectives of this project were to 1) determine the mutual influences of $\mathrm{Hg}$ and Se on one another's uptake, retention and tissue distributions by utilizing specified dietary conditions in a controlled laboratory animal study and analyzing elemental concentrations in the tissues; 2) examine direct interactions between $\mathrm{Hg}$ and $\mathrm{Se}$ by measuring bound $\mathrm{Hg}-\mathrm{Se}$ ratios in tissue samples using x-ray absorption fine structure (XAFS) analysis; and 3) further the development of a computation method of interpreting and evaluating research data by using the Physiologically Oriented Integration of Nutrients and Toxins (POINT) model reflecting the influence of $\mathrm{MeHg}$ on Se availability in various tissue compartments.

In order to meet the goals and objectives of the project, the research activities were divided into three tasks:

- Task 1: Accumulation, retention, and distribution of Se and $\mathrm{MeHg}$

- Task 2: MeHg binding affinities to thio vs. selenomolecules

- Task 3: Determination of the biochemical threshold of $\mathrm{MeHg}$ effects

\section{EXPERIMENTAL}

\section{Task 1 - Accumulation, Retention, and Distribution of Selenium and Methylmercury}

\section{Diet Preparation}

Diets used in this study were based on the AIN-93G formula for laboratory rodents customized through use of low Se torula yeast as the protein source (Teklad, Madison, Wisconsin). See Table 1 and 2 for composition details. Low-Se torula yeast basal diets measured by hydride generation atomic fluorescence spectroscopy (HG-AFS; PS Analytical, Deerfield Beach, Florida) were found to contain $0.24 \pm 0.13 \mu \mathrm{mol} \mathrm{Se} / \mathrm{kg}(0.019 \pm 0.010 \mathrm{ppm} \mathrm{Se})$. This is a low but nutritionally adequate level of Se for rodents (Reeves et al., 1993). The basal diets were augmented with $\mathrm{Na}_{2} \mathrm{SeO}_{4}$ to adjust $\mathrm{Se}$ concentrations to levels that reflect the nutritionally relevant range of dietary Se concentrations. Diets for this study were low-Se, adequate-Se, or rich-Se prepared to containing $\sim 0.25,0.50$, or $7.00 \mu \mathrm{mol} \mathrm{Se} / \mathrm{kg}(\sim 0.02,0.04$, or $0.55 \mathrm{ppm} \mathrm{Se})$ respectively. The $7.00 \mu \mathrm{mol} \mathrm{Se} / \mathrm{kg}$ concentration in the rich-Se diet is well below the $25 \mu \mathrm{mol}$ $\mathrm{Se} / \mathrm{kg}(\sim 2 \mathrm{ppm} \mathrm{Se})$ level that is accepted as a beneficial concentration in nutrition studies and is less than the average amount of Se present in typical varieties of ocean fish $(\sim 10 \mu \mathrm{mol} \mathrm{Se} / \mathrm{kg})$.

Each of the Se diets was prepared with either low, moderate, or high amounts 0.0, 0.5, or $70 \mu \mathrm{mol}$ of $\mathrm{MeHg} / \mathrm{kg} \quad(0.1,0.2$, or $14 \mathrm{ppm} \mathrm{MeHg})$ added in the following manner. Diets provided by Teklad were prepared with only $60 \mathrm{~g} / \mathrm{kg}$ of oil $/ \mathrm{kg},-1 \%$ less than the AIN-93 
Table 1. Modified Mineral Mix and Composition of AIN-93G Torula Yeast-Based Diets

\begin{tabular}{llll}
\hline Mineral Mix Composition & $\mathrm{g} / \mathrm{kg}$ & Diet Ingredients & $\mathrm{g} / \mathrm{kg}$ \\
\hline Calcium Carbonate, anhydrous, 40.04\% Ca & 555.26 & Torula yeast & 300 \\
Sodium Chloride, 39.34\% Na & 73.5 & DL-methionine & 6.7 \\
Copper Carbonate, 57.47\% Cu & 0.143 & Arginine & 0.1 \\
Potassium Iodate, 59.3\% I & 0.01 & Tryptophan & 0.3 \\
Ammonium Paramolybdate, 4 Hydrate, 54.34\% Mo & 0.008 & Soybean oil & 70 \\
Sodium Metasilicate, 9 Hydrate, 9.88\% Si & 1.45 & Mineral mix & 35 \\
Chromium Potassium Sulfate, 12 Hydrate, 10.42\% Cr & 0.275 & Cellulose & 50 \\
Lithium Chloride, $16.38 \% \mathrm{Li}$ & 0.017 & Mix & 10 \\
Boric Acid, 17.5\% B & 0.082 & Choline bitartrate & 1 \\
Sodium Flouride, 45.24\% F & 0.064 & & \\
Nickel Carbonate, $45 \% \mathrm{Ni}$ & 0.032 & & \\
Ammonium Vanadate, 43.55\% V & 0.007 & & 1000 \\
Powdered Sucrose & 369.15 & & \\
\hline Total & 1000 & Total & \\
\hline
\end{tabular}

Sodium selenite additions replaced sucrose in Se-supplemented diets. Mineral mix was added at $35 \mathrm{~g} / \mathrm{kg}$ $(3.5 \%)$ of total diet prior to mixing.

Table 2. Molar Ratios in Diets

\begin{tabular}{lccc}
\hline & \multicolumn{3}{c}{ Dietary Se Content } \\
\hline Dietary MeHg Content & $0.25 \mu \mathrm{mol} \mathrm{Se} / \mathrm{kg}$ & $0.5 \mu \mathrm{mol} \mathrm{Se} / \mathrm{kg}$ & $7.0 \mu \mathrm{mol} \mathrm{Se} / \mathrm{kg}$ \\
\hline $0.5 \mu \mathrm{mol} \mathrm{MeHg} / \mathrm{kg}$ & 2.00 & 1.00 & 0.07 \\
$1.0 \mu \mathrm{mol} \mathrm{MeHg} / \mathrm{kg}$ & 4.00 & 2.00 & 0.14 \\
$70 \mu \mathrm{mol} \mathrm{MeHg} / \mathrm{kg}$ & 280.00 & 140.00 & 10.00
\end{tabular}

Sodium selenite additions replaced sucrose in Se-supplemented diets. Mineral mix was added at $35 \mathrm{~g} / \mathrm{kg} \mathrm{(3.5 \% )}$ of total diet prior to mixing.

recommended levels. This purposeful omission allowed $\mathrm{MeHg}$ to be added in safflower oil to be added at (1\% wt $/ \mathrm{wt}$ basis) to complete the $70 \mathrm{~g} / \mathrm{kg}$ recommended for this diet. Required amounts of $\mathrm{MeHgCl}$ (Sigma-Aldrich, St. Louis, Missouri) were dissolved in safflower oil and mixed for 30 minutes to ensure homogeneous distribution.

Diets were prepared in $1.5 \mathrm{~kg}$ batches using $15 \mathrm{~g}$ of oil distributed evenly over $1485 \mathrm{~g}$ and completely mixed together for 5 minutes to obtain an even distribution of $\mathrm{MeHg}$ in the diet. After mixing, representative fractions of these diets were set aside for total $\mathrm{Hg}$ analysis. Diets that had been prepared with $0.0 \mathrm{MeHg}$ added were found to contain $0.51 \pm 0.35 \mu \mathrm{mol} \mathrm{Hg} / \mathrm{kg}$ $(0.10 \pm 0.07 \mathrm{ppm} \mathrm{Hg})$, apparently arising in conjunction with component materials comprising the basal diet. This level of $\mathrm{Hg}$ contamination is similar to what has previously been observed in laboratory animal diets (Weiss et al., 2005) Therefore, the actual $\mathrm{Hg}$ concentrations in the diet after the $\mathrm{MeHg}$ additions were $\sim 0.5,1.0$, and $70 \mu \mathrm{mol} \mathrm{MeHg} / \mathrm{kg}(0.1,0.2$, and $14.2 \mathrm{ppm} \mathrm{Hg})$.

The Hg:Se molar ratios for these diets are shown in Table 2. As can be observed in the table, the Hg:Se ratios run from highly toxic (280) to relatively low (0.7). It is significant to note that the Hg:Se ratio in ocean fish approximately corresponds to the lowest $\mathrm{Hg}$ :Se ratio used in 
this study (0.7). The mass quantities of $\mathrm{Hg}$ exposure would be greater than occur in this diet, but the $\mathrm{Hg}$ :Se molar ratio would be very similar.

\section{Animal Study}

The 72 weanling male Long Evans rats were pseudorandomly divided into nine weight matched groups (eight rats/group) with equivalent mean body weights $(128.2 \pm 1.5 \mathrm{~g}$ ) that were randomly assigned to one of the nine dietary treatments (three levels of Se, three levels of $\mathrm{MeHg}$, in a fully crossed $3 \times 3$ feeding study design). Rats from each treatment group were individually maintained in polyethylene plastic cages provided with deionized water and their designated diets constantly provided ab libitum. Treatment groups were housed in an animal facility with room temperature maintained at $28^{\circ} \mathrm{C}$, humidity at $53 \%$, and a 12-h light-12-h dark cycle. Food consumption, body weight, and motor function of the rats were monitored twice weekly to recognize and quantify onset and development of anorexia, growth inhibition, impaired growth efficiency, and neurological defect end points as signs and symptoms of $\mathrm{MeHg}$ toxicity that might develop during the 9 week study. Diet-dependent differences in food consumption, growth, and growth efficiency were analyzed using ANOVA to assess $\mathrm{Hg}-\mathrm{Se}$ interactions and compared using t-tests (Microsoft Office Excel, http://office.microsoft.com). On day 63 of the study, rats were intraperitoneally injected with ketamine-rompun (mixed 1:1.37) at a constant $1 \mu \mathrm{L} / \mathrm{g}$ body weight dosage. Toenail samples were collected from the anaesthetized animals using stainless steel clippers. Syringes prepared with $\mathrm{K}_{2}$ EDTA were used to collect $10-15 \mathrm{~mL}$ of blood via cardiac exsanguination. Blood samples were mixed by repeated inversion and stored in an ice bath prior to centrifugation for 15 minutes at $1600 \times \mathrm{g}$ and separation into plasma and packed cells. Tissues were removed, cleared of exogenous materials, rinsed in normal saline, patted dry, wrapped in prelabeled aluminum foils, and flash-frozen in liquid nitrogen. Samples were stored at $-85^{\circ} \mathrm{C}$ until ready for elemental analysis.

\section{Sample Analysis}

Diets and blood samples of $\sim 0.2 \mathrm{~g}$ were weighed into single use, trace element-free $50-\mathrm{mL}$ digestion tubes (Environmental Express, Mt. Pleasant, South Carolina 29464), with every tenth sample being prepared in duplicate and with elemental spike recovery samples being prepared accompanying each batch. Each digestion batch included analysis blanks and certified reference materials (dogfish muscle certified reference material DORM-2, National Research Council of Canada, Ottawa, Ontario, Canada).

Samples were treated with $5 \mathrm{~mL}$ of $\mathrm{HNO}_{3}$ (Fisher Trace Metal Grade, Fisher Scientific, www.fishersci.com) and heated at $85^{\circ} \mathrm{C}$ in deep cell hot blocks (Environmental Express) for 24 hours in capped tubes to preserve samples from trace element contamination. Samples were cooled, $1.5 \mathrm{~mL}$ of $30 \% \mathrm{H}_{2} \mathrm{O}_{2}$ (Fisher Certified A.C.S., Fisher Scientific) was added, and samples were recapped and returned to heating in the dry block at $85^{\circ} \mathrm{C}$ for 8 hours more. Samples were cooled and $15 \mathrm{~mL}$ of $12 \mathrm{~N} \mathrm{HCl}$ (Fisher Trace Metal Grade, Fisher Scientific) were added. Samples were heated at $90^{\circ} \mathrm{C}$ for 90 minutes to reduce SeVI to SeIV. Samples were cooled, and diluted to $50 \mathrm{~mL}$ with double distilled water. Samples were further diluted into instrumental calibration ranges and analyzed for $\mathrm{Hg}$ content by cold-vapor atomic absorption spectrophotometry using a CETAC M-6000A (CETAC Technologies, Omaha, Nebraska), and 
Se was analyzed by hydride generation atomic absorption spectroscopy using a PS Analytical Dual Millenium Excalibur (PS Analytical, Deerfield Beach, Florida). Before data from sample analysis runs were entered into the database, $\mathrm{MeHg}$ and $\mathrm{Se}$ concentrations in sample digestion blanks and elemental recoveries in samples of certified reference materials were evaluated to qualify the analysis batch data for inclusion. The Se and $\mathrm{Hg}$ contents of liver, kidney, testes, brain, pituitary, and toenail samples were determined using standard comparator neutron activation analysis and the ${ }^{74} \mathrm{Se}(\mathrm{n}, \gamma) 75 \mathrm{Se}$ and the $202 \mathrm{Hg}(\mathrm{n}, \gamma){ }^{203} \mathrm{Hg}$ reactions. The toenails and freeze-dried tissue samples were weighed and sealed into clean quartz vials. The samples were irradiated for 50 hours at a flux of ca. $5 \times 10^{13} \mathrm{n} \cdot \mathrm{cm}^{-2} \cdot \mathrm{s}^{-1}$ and allowed to decay for several weeks. Samples, standards, and QC materials were live-time-counted for 4 hours using an automated sample changer. In some samples, a large background impeded integration of the $136.0 \mathrm{keV}$ gamma ray peak from ${ }^{75} \mathrm{Se}$. For this reason, only the $279 / 264 \mathrm{keV}$ ratio was used to subtract the ${ }^{75} \mathrm{Se}$ contribution from the total $279 \mathrm{keV}$ peak in these sample spectra. All samples were blank subtracted and corrected for the possible Se interferences: ${ }^{182} \mathrm{Ta},{ }^{181} \mathrm{~W}$, and ${ }^{181} \mathrm{Hf}$.

Total $\mathrm{Hg}$ and Se mass concentrations (parts per million) for each sample were converted to molar concentrations (micromole per kilogram). Means and standard deviations of molar concentrations of $\mathrm{Hg}$ and $\mathrm{Se}$ were calculated and graphed for each tissue. Elemental concentrations of $\mathrm{Hg}$ and $\mathrm{Se}$ in tissues of different dietary treatment groups were analyzed using ANOVA to assess $\mathrm{Hg}-\mathrm{Se}$ interactions and compared using t-tests (Microsoft Office Excel, http://office.microsoft.com).

\section{Task 2 - MeHg Binding Affinities to Thio vs. Selenomolecules}

During performance of this task, the suitability and superiority of XAFS, a spectroscopic method that uses x-rays to probe the physicochemical structure of matter at the atomic scale became obvious. Rather than indirectly assess $\mathrm{Hg}-\mathrm{S}$ vs. $\mathrm{Hg}-\mathrm{Se}$ binding in an in vitro system as originally conceived, this task was modified to investigate the actual biologically occurrence of $\mathrm{Hg}-\mathrm{S}$ vs. Hg-Se molecules in mammalian tissue samples. Whale liver tissues collected from stranded beluga and pygmy sperm whales were provided by the National Oceanic and Atmospheric Administration. The $\mathrm{Hg}$ bound to thio vs. selenomolecules in these tissues was determined with XAFS analysis in collaboration with Dr. Frank Huggins of the University of Kentucky. XAFS spectra of $\mathrm{Hg}$ and Se species occurring in whale liver samples were compared to authentic molecular forms used as analytical standards.

\section{Task 3 - Determination of the Biochemical Threshold of Methylmercury Effects}

Physiologically based PharmacoKinetic (PBPK) models have been used as a method of determining mathematical reflections of the toxicodynamics of $\mathrm{MeHg}$ and its metabolites (Byczkowski, 2005; Smith and Farris, 1996; Young et al., 2001; Shipp et al., 2000; Kirman et al., 2003; Clewell et al., 1999; Gray, 1995). However, these models have not considered the influence of Se physiology in assessing MeHg toxicity risk. Therefore, in order to assess the influence of $\mathrm{MeHg}$ on Se availability in various tissue compartments, the PBPK model was extended into a more comprehensive POINT version. Since Se physiology and its distributions in tissue compartments are fairly well understood (Zachara et al., 2001; Kaneko et al., 1999; 
Westermarck, 1977; Behne et al., 1996), POINT models of $\mathrm{Hg}-\mathrm{Se}$ interaction studies can readily be integrated with the established PBPK models.

Therefore, this project extends the PBPK model of $\mathrm{MeHg}$ exposure into a calculated POINT model that incorporates a balanced toxicological and physiological perspective of the observed food consumptions, weight gains, and motor function abilities of experimental animals fed diets containing graduated concentrations of $\mathrm{Se}$ and $\mathrm{MeHg}$. The symptoms of $\mathrm{MeHg}$ toxicity were assessed in relation to Se dietary intakes and bioavailability by using POINT model computations of $\mathrm{MeHg}$ and Se intakes, absorption and excretion rates, and their calculated demethylation and complexation rates. This POINT model is currently used to evaluate and interpret the animal study results, including results from complementary rat studies, but ultimately, this model can be extended for evaluations of human exposures to $\mathrm{MeHg}$ and the consequent effects on Se physiology.

\section{RESULTS AND DISCUSSION}

Task 1 - Accumulation and Distribution of Selenium and Methylmercury Effects of Dietary MeHg and Se on Growth

One of the more prominent signs of $\mathrm{Hg}$ toxicity in experimental animals is depressed growth. To monitor MeHg toxicity and the effects of dietary Se status, individual body weights were measured weekly and plotted to reveal dose- and time-dependent effects.

Weight gains by rats fed low-Se $(0.25 \mu \mathrm{mol} \mathrm{Se} / \mathrm{kg})$, adequate-Se $(0.50 \mu \mathrm{mol} \mathrm{Se} / \mathrm{kg})$, and rich-Se $(7.00 \mu \mathrm{mol} \mathrm{Se} / \mathrm{kg})$ diets without added $\mathrm{MeHg}$ were not significantly different. When $\mathrm{MeHg}$ exposure was low $(0.5 \mu \mathrm{mol} \mathrm{MeHg} / \mathrm{kg})$ or moderate $(1.0 \mu \mathrm{mol} \mathrm{MeHg} / \mathrm{kg})$, the level of dietary Se had little effect on growth rates of weanling rats (Figure $2 \mathrm{a}$ and $2 \mathrm{~b}$ ). However, when $\mathrm{MeHg}$ was present at $70 \mu \mathrm{mol} \mathrm{MeHg} / \mathrm{kg}$ diet, weight gains by rats fed low-Se diets were significantly less than rats fed adequate-Se or rich-Se diets (see Figure 2c).

\section{Effects of Dietary MeHg and Se on Elemental Distributions in Kidney}

Consistent with previous work, this study finds high levels of $\mathrm{Se}$ and $\mathrm{Hg}$ accumulate in kidney. After 9 weeks of dietary treatment, Se contents in kidneys of rats fed adequate Se with low $\mathrm{MeHg}(0.5 \mu \mathrm{mol} \mathrm{Se} / \mathrm{kg}$; $0.5 \mu \mathrm{mol} \mathrm{MeHg} / \mathrm{kg}$; hereafter referred to as normal diets) were $57.48 \pm 4.76 \mu \mathrm{mol} \mathrm{Se} / \mathrm{kg}$. Dietary Se levels were $\sim 80 \%$ lower in kidneys of rats fed low-Se diets, and $\sim 100 \%$ higher in rats fed rich-Se diets in the absence of $\mathrm{MeHg}$ exposure (Table 3).

Dietary Se exposure was reflected in kidney Se levels when $\mathrm{MeHg}$ exposure was low but was accentuated by high $\mathrm{MeHg}$ exposure, resulting in dramatic increases $(\sim 100 \%)$ when dietary Se was at adequate levels and almost $900 \%$ in rats fed rich-Se diets. Kidney Hg:Se ratios were 70.8 in low-Se rats, 15.2 in adequate-Se rats, and 3.1 in rats fed rich dietary Se. High $\mathrm{MeHg}$ exposure increased Se retention in kidneys. 

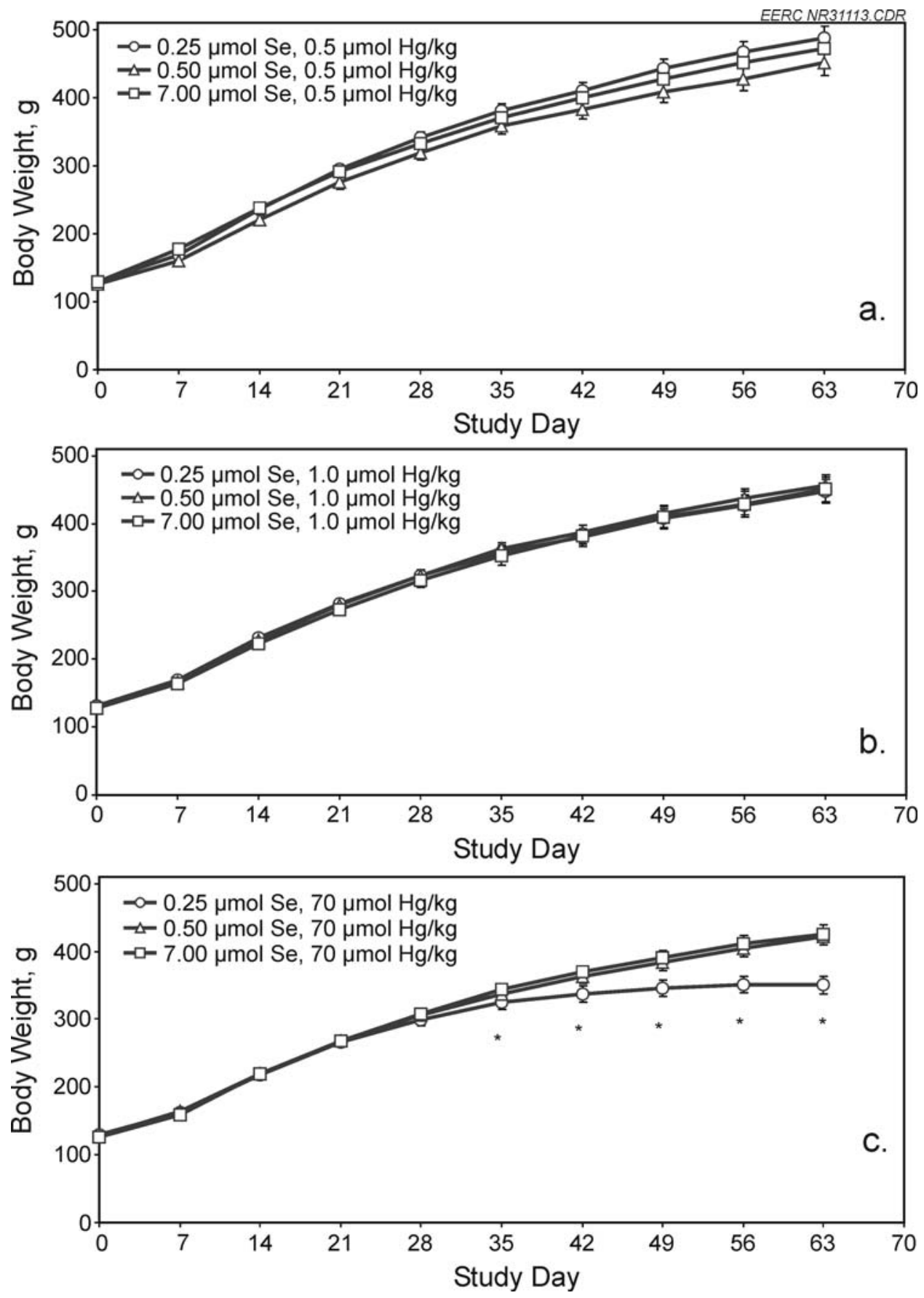

Figure 2. Growth of rats fed diets containing graduated quantities of MeHg and Se. Data depict means \pm standard deviations for group body weights (in grams) at the times indicated. Asterisks indicate statistically significant differences $(p<0.05)$ between growth of treatment groups. 
Table 3. Kidney Dry-Weight Basis

\begin{tabular}{lccc}
\hline Effect of Diet on Se Content & \multicolumn{3}{c}{ Dietary Se Content } \\
\hline Dietary MeHg Content & $0.25 \mu \mathrm{mol} \mathrm{Se} / \mathrm{kg}$ & $0.5 \mu \mathrm{mol} \mathrm{Se} / \mathrm{kg}$ & $7.0 \mu \mathrm{mol} \mathrm{Se} / \mathrm{kg}$ \\
\hline $0.5 \mu \mathrm{mol} \mathrm{MeHg} / \mathrm{kg}$ & $13.23 \pm 2.84^{\mathrm{a}}$ & $57.48 \pm 4.76^{\mathrm{b}}$ & $110.09 \pm 13.26^{\mathrm{c}}$ \\
$1.0 \mu \mathrm{mol} \mathrm{MeHg} / \mathrm{kg}$ & $12.19 \pm 2.21^{\mathrm{a}}$ & $60.53 \pm 6.48^{\mathrm{b}}$ & $107.10 \pm 14.87^{\mathrm{c}}$ \\
$70 \mu \mathrm{mol} \mathrm{MeHg} / \mathrm{kg}$ & $17.48 \pm 2.13^{\mathrm{d}}$ & $110.27 \pm 14.48^{\mathrm{e}}$ & $563.45 \pm 142.01^{\mathrm{f}}$ \\
& & & \\
\hline Effect of Diet on Hg Content & \multicolumn{3}{c}{ Dietary Se Content } \\
\hline \multicolumn{5}{c}{$0.5 \mu \mathrm{mol} \mathrm{Se} / \mathrm{kg}$} & $7.0 \mu \mathrm{mol} \mathrm{Se} / \mathrm{kg}$ \\
\hline Dietary MeHg Content & $0.25 \mu \mathrm{mol} \mathrm{Se} / \mathrm{kg}$ & $1.26 \pm 0.97^{\mathrm{a}}$ & $0.88 \pm 0.29^{\mathrm{a}}$ \\
$0.5 \mu \mathrm{mol} \mathrm{MeHg} / \mathrm{kg}$ & $0.85 \pm 0.45^{\mathrm{a}}$ & $17.46 \pm 3.59^{\mathrm{c}}$ & $15.52 \pm 3.08^{\mathrm{c}}$ \\
$1.0 \mu \mathrm{mol} \mathrm{MeHg} / \mathrm{kg}$ & $10.43 \pm 5.23^{\mathrm{b}}$ & $167.00 \pm 239.40^{\mathrm{e}}$ & $1765.44 \pm 241.81^{\mathrm{e}}$ \\
$70 \mu \mathrm{mol} \mathrm{MeHg} / \mathrm{kg}$ & $1238.35 \pm 122.72^{\mathrm{d}}$ & 1673.04
\end{tabular}

Values shown in the table reflect means \pm SD (dry weight basis) of tissues collected from animals fed the indicated levels of Se and $\mathrm{MeHg}$ for 63 days ( $n=8$ per group). Values with different superscripts are statistically different from one another $(\mathrm{p}<0.05)$.

\section{Effects of Dietary MeHg and Se on Elemental Distributions in Liver}

The contents of Se observed in liver tissues of rats fed low-, adequate-, or rich-Se diets were consistent with observations reported in previous studies. As with kidney, the Se distribution in liver was indirectly proportional to dietary intake because of normal homeostatic control processes (see Table 4).

Livers from rats fed normal diets contained $33.76 \pm 3.30 \mu \mathrm{mol} \mathrm{Se} / \mathrm{kg}$. In rats fed low-Se diets, liver Se diminished to less than $5 \%$ of normal. Dietary Se exposure was consistently reflected in liver Se levels when $\mathrm{MeHg}$ exposure was low, but compared to normal rats, high $\mathrm{MeHg}$ exposure resulted in dramatic $\sim 400 \%$ increases in Se in livers of rats fed rich-Se diets. High $\mathrm{MeHg}$ exposures resulted in slightly increased Se retention in livers of rats fed low dietary Se but did not affect Se retention in rats fed adequate dietary Se.

Accumulation of $\mathrm{Hg}$ in liver was directly proportional to dietary MeHg at each level of dietary Se but tended to increase with increasing dietary Se intakes when MeHg exposures were high. The proportional distribution of $\mathrm{Hg}$ and $\mathrm{Se}$ in liver resulted in $\mathrm{Hg}$ :Se ratios of 146.5 in rats fed low-Se diets, 11.0 in rats fed adequate-Se diets, and 2.8 in rats fed rich-Se diets.

\section{Effects of Dietary MeHg and Se on Elemental Distributions in Testes}

The effects of MeHg on testes Se contents has not been previously studied. The contents of Se observed in testes of rats fed low-, adequate-, or rich-Se diets were less sensitive to dietary Se and $\mathrm{MeHg}$ than any other tissue (see Table 5). 
Table 4. Liver Dry-Weight Basis

\begin{tabular}{llll}
\hline Effect of Diet on Se Content & & & \\
\hline & & Dietary Se Content & \\
\hline Dietary MeHg Content & $0.25 \mu \mathrm{mol} \mathrm{Se} . \mathrm{kg}$ & $0.5 \mu \mathrm{mol} \mathrm{Se} . \mathrm{kg}$ & $7.0 \mu \mathrm{mol} \mathrm{Se} . \mathrm{kg}$ \\
\hline $0.5 \mu \mathrm{mol} \mathrm{MeHg} / \mathrm{kg}$ & $1.48 \pm 0.19^{\mathrm{a}}$ & $33.76 \pm 3.30^{\mathrm{b}}$ & $72.66 \pm 23.53^{\mathrm{c}}$ \\
$1.0 \mu \mathrm{mol} \mathrm{MeHg} / \mathrm{kg}$ & $1.49 \pm 0.24^{\mathrm{a}}$ & $34.07 \pm 4.48^{\mathrm{b}}$ & $79.81 \pm 12.06^{\mathrm{c}}$ \\
$70 \mu \mathrm{mol} \mathrm{MeHg} / \mathrm{kg}$ & $2.14 \pm 0.31^{\mathrm{d}}$ & $33.34 \pm 3.68^{\mathrm{b}}$ & $165.35 \pm 38.96^{\mathrm{e}}$ \\
& & & \\
\hline Effect of Diet on Hg Content & & & \\
\hline \multicolumn{5}{l}{ Dietary Se Content } \\
\hline Dietary MeHg Content & $0.25 \mu \mathrm{mol} \mathrm{Se} / \mathrm{kg}$ & $0.5 \mu \mathrm{mol} \mathrm{Se} / \mathrm{kg}$ & $7.0 \mu \mathrm{mol} \mathrm{Se} / \mathrm{kg}$ \\
\hline $0.5 \mu \mathrm{mol} \mathrm{MeHg} / \mathrm{kg}$ & $0.06 \pm 0.03^{\mathrm{a}}$ & $0.04 \pm 0.03^{\mathrm{a}}$ & $0.15 \pm 0.12^{\mathrm{a}}$ \\
$1.0 \mu \mathrm{mol} \mathrm{MeHg} / \mathrm{kg}$ & $2.07 \pm 0.78^{\mathrm{b}}$ & $1.77 \pm 0.25^{\mathrm{b}}$ & $2.79 \pm 0.33^{\mathrm{c}}$ \\
$70 \mu \mathrm{mol} \mathrm{MeHg} / \mathrm{kg}$ & $313.20 \pm 54.83^{\mathrm{d}}$ & $365.58 \pm 106.19^{\mathrm{d}, \mathrm{e}}$ & $470.14 \pm 83.19^{\mathrm{e}}$ \\
\hline
\end{tabular}

Values shown in the table reflect means \pm SD (dry weight basis) of tissues collected from animals fed the indicated levels of Se and $\mathrm{MeHg}$ for 63 days $(\mathrm{n}=8$ per group). Values with different superscripts are statistically different from one another $(\mathrm{p}<0.05)$.

Table 5. Testes Dry-Weight Basis

\begin{tabular}{|c|c|c|c|}
\hline \multicolumn{4}{|c|}{ Effect of Diet on Se Content } \\
\hline & \multicolumn{3}{|c|}{ Dietary Se content } \\
\hline Dietary MeHg Content & $0.25 \mu \mathrm{mol} \mathrm{Se} / \mathrm{kg}$ & $0.5 \mu \mathrm{mol} \mathrm{Se} / \mathrm{kg}$ & $7.0 \mu \mathrm{mol} \mathrm{Se} / \mathrm{kg}$ \\
\hline $0.5 \mu \mathrm{mol} \mathrm{MeHg} / \mathrm{kg}$ & $61.53 \pm 4.09^{\mathrm{a}}$ & $74.79 \pm 4.94^{b}$ & $90.73 \pm 9.55^{c}$ \\
\hline $1.0 \mu \mathrm{mol} \mathrm{MeHg} / \mathrm{kg}$ & $59.99 \pm 9.07^{\mathrm{a}}$ & $78.54 \pm 4.03^{\mathrm{b}, \mathrm{d}}$ & $81.02 \pm 3.3^{\mathrm{d}}$ \\
\hline $70 \mu \mathrm{mol} \mathrm{MeHg} / \mathrm{kg}$ & $51.75 \pm 4.68^{\mathrm{e}}$ & $60.35 \pm 4.11^{\mathrm{a}}$ & $79.33 \pm 7.9^{\mathrm{b}, \mathrm{d}}$ \\
\hline \multicolumn{4}{|c|}{ Effect of Diet on Hg Content } \\
\hline & \multicolumn{3}{|c|}{ Dietary Se content } \\
\hline Dietary MeHg Content & $0.25 \mu \mathrm{mol} \mathrm{Se} / \mathrm{kg}$ & $0.5 \mu \mathrm{mol} \mathrm{Se} / \mathrm{kg}$ & $7.0 \mu \mathrm{mol} \mathrm{Se} / \mathrm{kg}$ \\
\hline $0.5 \mu \mathrm{mol} \mathrm{MeHg} / \mathrm{kg}$ & $0.03 \pm 0.01^{\mathrm{a}}$ & $0.16 \pm 0.05^{b}$ & $0.08 \pm 0.13^{\mathrm{a}, \mathrm{b}}$ \\
\hline $1.0 \mu \mathrm{mol} \mathrm{MeHg} / \mathrm{kg}$ & $0.82 \pm 0.13^{\mathrm{c}}$ & $0.75 \pm 0.07^{\mathrm{c}}$ & $1.48 \pm 0.16^{\mathrm{d}}$ \\
\hline $70 \mu \mathrm{mol} \mathrm{MeHg} / \mathrm{kg}$ & $182.05 \pm 21.67^{\mathrm{e}}$ & $227.50 \pm 16.57^{\mathrm{f}}$ & $236.96 \pm 37.01^{f}$ \\
\hline
\end{tabular}

Testes from rats fed normal diets contained $74.79 \pm 4.94 \mu \mathrm{mol} \mathrm{Se} / \mathrm{kg}$, higher than any other tissue included in this study. In rats fed low-Se diets, testes Se diminished only slightly. These results indicate testes Se is highly conserved when dietary Se intakes are low. In contrast to liver and kidney where Se contents tended to increase with increasing dietary MeHg exposure, testes Se contents diminished significantly with increasing $\mathrm{MeHg}$ exposure. The reason why this occurs is not known but may reflect $\mathrm{MeHg}$ interference with synthesis of molecular forms of Se in blood that normally ensure optimal Se is delivered to these organs. Another possibility is that $\mathrm{MeHg}$ may bind to selenocysteines of selenomolecules, limiting their uptake from the blood. 
Accumulation of $\mathrm{Hg}$ in testes was proportional to dietary $\mathrm{MeHg}$ at each level of dietary Se but increased with increasing dietary Se intakes. The proportional distribution of $\mathrm{Hg}$ and $\mathrm{Se}$ in testes of rats fed high $\mathrm{MeHg}$ diets resulted in $\mathrm{Hg}: \mathrm{Se}$ ratios of 3.5, 3.8, and 3.0 in rats fed low-, adequate-, and rich-Se diets, respectively. Therefore, $\mathrm{MeHg}$ was less dramatically in excess of Se in testes than in any of the other tissues, possibly because of its high native Se contents.

\section{Effects of Dietary MeHg and Se on Elemental Distributions in Pituitary}

The effects of MeHg on pituitary Se contents has not been previously studied. Levels of Se in pituitaries of rats fed adequate-Se diets were consistent with observations reported in previous studies. As with other tissues, Se contents of pituitary were indirectly proportional to dietary intake because of normal homeostatic control processes (Table 6).

Pituitaries of rats fed normal diets contained 28.19 $\pm 9.36 \mu \mathrm{mol} \mathrm{Se} / \mathrm{kg}$. Dietary Se intakes were reflected in pituitary Se levels, but accumulation was accentuated by $\mathrm{MeHg}$ exposure when dietary Se was rich. Pituitaries of rats that consumed high Se increased 2-fold Se when dietary $\mathrm{MeHg}$ exposure was moderate and almost 3-fold when $\mathrm{MeHg}$ exposure was high. $\mathrm{MeHg}$ concentrations in pituitary increased with increasing dietary Se intakes. When dietary Se was low and $\mathrm{MeHg}$ was high, the Se concentration in pituitary diminished to $\sim 50 \%$ of normal. Since there was $\sim 15$ times as much $\mathrm{Hg}$ as $\mathrm{Se}$ in these pituitary tissues, it is possible that little free $\mathrm{Se}$ was available. Although the $\mathrm{Hg}: \mathrm{Se}$ molar ratio in pituitary was nearly the same in rats fed high $\mathrm{MeHg}$ along with adequate Se $(\sim 14)$, the additional Se arising from the daily diet was sufficient to support normal growth, possibly as a result of maintaining normal Se physiology in their pituitaries. The $\mathrm{Hg}$ :Se molar ratio in rats fed rich $\mathrm{Se}$, high $\mathrm{MeHg}$ diets was 4.6, but the total amount of Se present had more than doubled.

Table 6. Pituitary Dry-Weight Basis

\begin{tabular}{lccc}
\hline Effect of Diet on Se Content & \multicolumn{3}{c}{ Dietary Se Content } \\
\hline Dietary MeHg Content & $0.25 \mu \mathrm{mol} \mathrm{Se} / \mathrm{kg}$ & $0.5 \mu \mathrm{mol} \mathrm{Se} / \mathrm{kg}$ & $7.0 \mu \mathrm{mol} \mathrm{Se} / \mathrm{kg}$ \\
\hline $0.5 \mu \mathrm{mol} \mathrm{MeHg} / \mathrm{kg}$ & $21.82 \pm 5.84 \mathrm{a}$ & $28.19 \pm 9.36 \mathrm{a}$ & $46.75 \pm 10.47 \mathrm{~b}$ \\
$1.0 \mu \mathrm{mol} \mathrm{MeHg} / \mathrm{kg}$ & $24.28 \pm 12.59 \mathrm{a}, \mathrm{d}$ & $29.49 \pm 12.07 \mathrm{a}, \mathrm{b}, \mathrm{d}$ & $53.19 \pm 10.05 \mathrm{~b}$ \\
$70 \mu \mathrm{mol} \mathrm{MeHg} / \mathrm{kg}$ & $15.30 \pm 7.38 \mathrm{~d}$ & $26.17 \pm 8.59 \mathrm{a}, \mathrm{d}$ & $80.30 \pm 12.97 \mathrm{e}$
\end{tabular}

\begin{tabular}{lccc}
\hline Effect of Diet on Hg Content & \multicolumn{3}{c}{ Dietary Se Content } \\
\hline Dietary MeHg Content & $0.25 \mu \mathrm{mol} \mathrm{Se} / \mathrm{kg}$ & $0.5 \mu \mathrm{mol} \mathrm{Se} / \mathrm{kg}$ & $7.0 \mu \mathrm{mol} \mathrm{Se} / \mathrm{kg}$ \\
\hline $0.5 \mu \mathrm{mol} \mathrm{MeHg} / \mathrm{kg}$ & $0.59 \pm 0.52 \mathrm{a}$ & $0.52 \pm 0.4 \mathrm{a}$ & $0.75 \pm 0.27 \mathrm{a}$ \\
$1.0 \mu \mathrm{mol} \mathrm{MeHg} / \mathrm{kg}$ & $2.21 \pm 0.59 \mathrm{~b}$ & $1.94 \pm 0.69 \mathrm{~b}$ & $3.00 \pm .052 \mathrm{c}$ \\
$70 \mu \mathrm{mol} \mathrm{MeHg} / \mathrm{kg}$ & $232.44 \pm 61.46 \mathrm{~d}$ & $370.46 \pm 127.47 \mathrm{~d}, \mathrm{e}$ & $368.84 \pm 41.25 \mathrm{e}$ \\
\hline
\end{tabular}

Values shown in the table reflect means \pm SD (dry weight basis) of tissues collected from animals fed the indicated levels of $\mathrm{Se}$ and $\mathrm{MeHg}$ for 63 days ( $\mathrm{n}=8$ per group). Values with different superscripts are statistically different from one another $(\mathrm{p}<0.05)$. 


\section{Effects of Dietary MeHg and Se on Elemental Distributions in Brain}

The effects of $\mathrm{MeHg}$ on brain Se contents have not been well examined in previous studies. Levels of Se in brains of rats fed adequate-Se diets were consistent with observations reported in previous studies (Table 7).

In contrast to Se distributions in somatic tissues that varied greatly depending on dietary $\mathrm{Se}$ intakes, brain Se contents were similar to Se in testes and pituitary in that only modest changes occurred in response to dietary manipulations. Brain Se diminished $15 \%$ when dietary Se diminished $50 \%$ and increased $11 \%$ when dietary Se increased more than tenfold. As with other tissues, dietary MeHg exposure was reflected in brain $\mathrm{Hg}$ levels. Dietary Se was reflected in brain $\mathrm{Se}$ levels when $\mathrm{Hg}$ exposure was low, but with high $\mathrm{Hg}$ exposure, Se concentrations increased $\sim 250 \%$ in rats fed rich-Se diets. High-MeHg diets resulted in brain $\mathrm{Hg}$ :Se ratios that were 26.9 in rats fed low-Se diets, 21.8 in rats fed adequate-Se diets, and 6.4 in rats fed rich-Se diets. High $\mathrm{MeHg}$ exposure resulted in notably severe decreases in brain Se contents to levels less than $60 \%$ of normal. In multigenerational Se deprivation studies, it has usually taken several generations to diminish brain Se to this degree. In this study, rats exposed to high-MeHg-low-Se diets resulted in these severe diminishments in brain Se in only 9 weeks. This rapid deprivation of brain Se appears to occur because of the combined synergistic effects of limited Se dietary supply and impaired Se redistribution from somatic tissues to the rapidly growing brain.

\section{Effects of Dietary MeHg and Se on Elemental Accumulation in Blood}

In human studies of $\mathrm{MeHg}$ exposure, $\mathrm{Hg}$ concentrations in blood are often measured as an indicator of $\mathrm{Hg}$ exposure. Although blood is an easily available sample source with immediate implications regarding current exposures and has proved to be somewhat adequate for quantifying $\mathrm{MeHg}$ exposure status, the utility of this measurement as an index of harm is less

Table 7. Brain Dry-Weight Basis

Effect of Diet on Se Content

\begin{tabular}{lccc}
\hline & \multicolumn{3}{c}{ Dietary Se Content } \\
\hline Dietary MeHg Content & $0.25 \mu \mathrm{mol} \mathrm{Se} / \mathrm{kg}$ & $0.5 \mu \mathrm{mol} \mathrm{Se} / \mathrm{kg}$ & $7.0 \mu \mathrm{mol} \mathrm{Se} / \mathrm{kg}$ \\
\hline $0.5 \mu \mathrm{mol} \mathrm{MeHg} / \mathrm{kg}$ & $5.54 \pm 0.24^{\mathrm{a}}$ & $6.54 \pm 0.52^{\mathrm{b}}$ & $7.23 \pm 0.88^{\mathrm{b}, \mathrm{c}}$ \\
$1.0 \mu \mathrm{mol} \mathrm{MeHg} / \mathrm{kg}$ & $5.51 \pm 0.43^{\mathrm{a}}$ & $6.78 \pm 0.44^{\mathrm{b}}$ & $8.53 \pm 1.06^{\mathrm{c}}$ \\
$70 \mu \mathrm{mol} \mathrm{MeHg} / \mathrm{kg}$ & $3.89 \pm 0.28^{\mathrm{d}}$ & $5.85 \pm 0.55^{\mathrm{a}}$ & $23.10 \pm 2.79^{\mathrm{e}}$
\end{tabular}

\begin{tabular}{lccc}
\hline Effect of Diet on Hg Content & & \\
\hline & & Dietary Se Content & \\
\hline Dietary MeHg Content & $0.25 \mu \mathrm{mol} \mathrm{Se} / \mathrm{kg}$ & $0.5 \mu \mathrm{mol} \mathrm{Se} / \mathrm{kg}$ & $7.0 \mu \mathrm{mol} \mathrm{Se} / \mathrm{kg}$ \\
\hline $0.5 \mu \mathrm{mol} \mathrm{MeHg} / \mathrm{kg}$ & $0.04 \pm 0.03^{\mathrm{a}}$ & $0.05 \pm 0.04^{\mathrm{a}}$ & $0.15 \pm 0.11^{\mathrm{a}}$ \\
$1.0 \mu \mathrm{mol} \mathrm{MeHg} / \mathrm{kg}$ & $0.79 \pm 0.15^{\mathrm{b}}$ & $0.90 \pm 0.16^{\mathrm{b}}$ & $3.23 \pm 0.87^{\mathrm{c}}$ \\
$70 \mu \mathrm{mol} \mathrm{MeHg} / \mathrm{kg}$ & $104.58 \pm 12.69^{\mathrm{d}}$ & $127.52 \pm 10.71^{\mathrm{d}, \mathrm{e}}$ & $149.04 \pm 18.47^{\mathrm{e}}$ \\
\hline
\end{tabular}

Values shown in the table reflect means \pm SD (dry weight basis) of tissues collected from animals fed the indicated levels of Se and MeHg for 63 days ( $n=8$ per group). Values with different superscripts are statistically different from one another $(\mathrm{p}<0.05)$. 
certain. The Hg contents in blood samples collected from the rat treatment groups are shown in Table 8. The results show direct relationships between dietary Se intakes and blood Se concentrations, and between $\mathrm{MeHg}$ exposure and blood $\mathrm{Hg}$ concentrations. The elemental concentrations in blood are on a wet-weight basis, while those shown for all other tissues are currently in a dry-weight format.

The normal blood Se concentration was $5.85 \pm 0.64$, but it diminished $\sim 75 \%$ when dietary Se was low and increased $\sim 70 \%$ when dietary Se intakes were rich. In rats fed adequate Se, increasing $\mathrm{MeHg}$ exposure tended to diminish blood Se contents, while in rats fed rich Se diets, increasing $\mathrm{MeHg}$ exposure resulted in a tendency toward increasing Se retention in blood. Hg:Se molar ratios in blood of rats fed high $\mathrm{MeHg}$ diets were 264.4 in rats fed low Se diets and in blood of rats fed adequate and rich dietary Se were respectively 83.3 and 31.0. In contrast to all other tissue types, the highest blood $\mathrm{Hg}$ concentrations were observed in rats fed high $\mathrm{MeHg}$ along with adequate Se.

\section{Effects of Dietary $\mathrm{MeHg}$ and Se on Elemental Accumulation in Toenails}

In human studies of $\mathrm{MeHg}$ exposure, $\mathrm{Hg}$ concentrations in toenails or blood are often measured as indicators of $\mathrm{Hg}$ exposure. Although toenails (Table 9) and blood have proved to be adequate for detecting and quantifying $\mathrm{MeHg}$ exposure, the utility of these measurements as an index of harm is less certain.

The results show a direct relationship between $\mathrm{MeHg}$ consumption and toenail $\mathrm{Hg}$ concentrations. The results show a positive relationship between $\mathrm{Hg}$ consumption and $\mathrm{Hg}$ levels. At low levels of $\mathrm{MeHg}$ exposure, Se status did not have a major influence on $\mathrm{Hg}$ deposition in toenails, but at high levels of $\mathrm{MeHg}$ exposure, there was greater distribution of $\mathrm{Hg}$ into toenails.

Table 8. Blood

\begin{tabular}{lccc}
\hline Effect of Diet on Se Content & \multicolumn{3}{c}{ Dietary Se Content } \\
\hline Dietary MeHg Content & $0.25 \mu \mathrm{mol} \mathrm{Se} / \mathrm{kg}$ & $0.5 \mu \mathrm{mol} \mathrm{Se} / \mathrm{kg}$ & $7.0 \mu \mathrm{mol} \mathrm{Se} / \mathrm{kg}$ \\
\hline $0.5 \mu \mathrm{mol} \mathrm{MeHg} / \mathrm{kg}$ & $1.32 \pm 0.22^{\mathrm{a}}$ & $5.85 \pm 0.64^{\mathrm{b}}$ & $9.77 \pm 1.98^{\mathrm{c}}$ \\
$1.0 \mu \mathrm{mol} \mathrm{MeHg} / \mathrm{kg}$ & $1.22 \pm 0.23^{\mathrm{a}}$ & $5.66 \pm 0.52^{\mathrm{b}}$ & $10.64 \pm 1.49^{\mathrm{c}}$ \\
$70 \mu \mathrm{mol} \mathrm{MeHg} / \mathrm{kg}$ & $1.18 \pm 0.28^{\mathrm{a}}$ & $4.85 \pm 0.88^{\mathrm{d}}$ & $11.05 \pm 1.26^{\mathrm{c}}$
\end{tabular}

\begin{tabular}{lccc}
\hline Effect of Diet on Hg Content & \multicolumn{3}{c}{ Dietary Se Content } \\
\hline Dietary MeHg Content & $0.25 \mu \mathrm{mol} \mathrm{Se} / \mathrm{kg}$ & $0.5 \mu \mathrm{mol} \mathrm{Se} / \mathrm{kg}$ & $7.0 \mu \mathrm{mol} \mathrm{Se} / \mathrm{kg}$ \\
\hline $0.5 \mu \mathrm{mol} \mathrm{MeHg} / \mathrm{kg}$ & $0.04 \pm 0.01^{\mathrm{a}}$ & $0.06 \pm 0.06^{\mathrm{a}}$ & $0.06 \pm 0.01^{\mathrm{a}}$ \\
$1.0 \mu \mathrm{mol} \mathrm{MeHg} / \mathrm{kg}$ & $1.57 \pm 0.11^{\mathrm{b}}$ & $1.53 \pm 0.18^{\mathrm{b}}$ & $1.76 \pm 0.23^{\mathrm{b}}$ \\
$70 \mu \mathrm{mol} \mathrm{MeHg} / \mathrm{kg}$ & $313.07 \pm 54.00^{\mathrm{c}}$ & $403.98 \pm 29.17^{\mathrm{d}}$ & $342.38 \pm 34.19^{\mathrm{c}}$ \\
\hline
\end{tabular}

Values shown in the table reflect means \pm SD (wet weight basis) of tissues collected from animals fed the indicated levels of Se and $\mathrm{MeHg}$ for 63 days ( $\mathrm{n}=8$ per group). Values with different superscripts are statistically different from one another $(\mathrm{p}<0.05)$. 
Table 9. Toenails

\begin{tabular}{lccc}
\hline Effects of Diet on Se Content & & Dietary Se Content \\
\hline Dietary MeHg Content & $0.25 \mu \mathrm{mol} \mathrm{Se} / \mathrm{kg}$ & $0.5 \mu \mathrm{mol} \mathrm{Se} / \mathrm{kg}$ & $7.0 \mu \mathrm{mol} \mathrm{Se} / \mathrm{kg}$ \\
\hline $0.5 \mu \mathrm{mol} \mathrm{MeHg} / \mathrm{kg}$ & $1.87 \pm 0.32^{\mathrm{a}}$ & $5.76 \pm 995^{\mathrm{b}}$ & $10.96 \pm 3358^{\mathrm{c}}$ \\
$1.0 \mu \mathrm{mol} \mathrm{MeHg} / \mathrm{kg}$ & $1.83 \pm 0.31^{\mathrm{a}}$ & $5.98 \pm 936^{\mathrm{b}}$ & $11.20 \pm 3063^{\mathrm{c}}$ \\
$7.0 \mu \mathrm{mol} \mathrm{MeHg} / \mathrm{kg}$ & $1.87 \pm 0.45^{\mathrm{a}}$ & $3.89 \pm 709^{\mathrm{d}}$ & $9.72 \pm 2623^{\mathrm{c}}$ \\
& & & \\
\hline Effect of Diet on Hg Content & & & \\
\hline & & Dietary Se Content & \\
\hline Dietary MeHg Content & $0.25 \mu \mathrm{mol} \mathrm{Se} / \mathrm{kg}$ & $0.5 \mu \mathrm{mol} \mathrm{Se} / \mathrm{kg}$ & $7.0 \mu \mathrm{mol} \mathrm{Se} / \mathrm{kg}$ \\
\hline $0.5 \mu \mathrm{mol} \mathrm{MeHg} / \mathrm{kg}$ & $0.66 \pm 0.28^{\mathrm{a}}$ & $1.00 \pm 0.30^{\mathrm{a}}$ & $1.25 \pm 0.73^{\mathrm{a}}$ \\
$1.0 \mu \mathrm{mol} \mathrm{MeHg} / \mathrm{kg}$ & $15.67 \pm 1.82^{\mathrm{b}}$ & $17.83 \pm 2.88^{\mathrm{b}}$ & $17.04 \pm 4.85^{\mathrm{b}}$ \\
$7.0 \mu \mathrm{mol} \mathrm{MeHg} / \mathrm{kg}$ & $2848.03 \pm 272.57^{\mathrm{c}}$ & $2610.93 \pm 596.70^{\mathrm{d}}$ & $3379.16 \pm 769.21^{\mathrm{c}}$ \\
\hline
\end{tabular}

Values shown in the table reflect means \pm SD (dry weight basis) of tissues collected from animals fed the indicated levels of Se and $\mathrm{MeHg}$ for 63 days ( $\mathrm{n}=8$ per group). Values with different superscripts are statistically different from one another $(\mathrm{p}<0.05)$.

The Se concentration in toenails of rats fed adequate-Se diets without added $\mathrm{MeHg}$ was $5.76 \pm 0.99 \mu \mathrm{mol} \mathrm{Se} / \mathrm{kg}$. Toenail Se declined $\sim 70 \%$ in rats fed low-Se diets and rose $\sim 90 \%$ in rats fed rich-Se diets. Dietary $\mathrm{MeHg}$ exposure did not affect Se distribution in toenails of rats on low Se diets, but $\mathrm{MeHg}$ caused declines in toenail Se in rats fed adequate- or rich-Se diets. As in all other tissues other than blood, the highest $\mathrm{Hg}$ accumulations were observed in rats fed high $\mathrm{MeHg}$ and rich dietary Se.

\section{Task 2 - In Vitro Examination of Direct Interactions between MeHg and Se}

The objective of this study was to determine bound $\mathrm{Hg}-\mathrm{Se}$ ratios in tissue samples using XAFS analysis. XAFS has become the technique of choice for determinations of trace element speciation in the complex systems that are typically encountered in environmental, geological, and biological sciences. Since toothed whales are large, long-lived mammals with high seafood consumption, they are a good model for examining physiological $\mathrm{Hg}$ and Se interactions and the trace element distribution in their tissues. Whale liver tissues were collected from stranded beluga and pygmy sperm whales provided courtesy of the National Oceanic and Atmospheric Administration. The proportions of $\mathrm{Hg}$ bound to thio and selenomolecules in these tissues were determined in collaboration with Dr. Frank Huggins of the University of Kentucky.

Multiple spectra were collected from each sample. Hg $\mathrm{L}_{\mathrm{III}}$ and $\mathrm{L}_{\mathrm{II}}$ XANES spectra of the whale liver samples were compared to spectra for $\mathrm{Hg}^{0}$, forms of mercuric oxide, mercuric nitrate, mercuric sulfide, and mercuric selenide. Based on the chemical analysis of forms of $\mathrm{Hg}$ and $\mathrm{Se}$ in the two whale liver samples, the bulk of the $\mathrm{Hg}$ present in this tissue is present as $\mathrm{HgSe}$. The molar ratio of $\mathrm{Hg}$ : $\mathrm{Se}$ is less than 1.0 for both, indicating that there is a molar excess of Se over $\mathrm{Hg}$ in the form of $\mathrm{HgSe}$ and therefore sufficient to maintain Se-dependent enzyme activities. No thiomolecule-bound $\mathrm{Hg}(\mathrm{HgS})$ was apparent in the observed spectra. Whereas $\mathrm{HgSe}$ constitutes about $67 \%$ of the total Se in Beluga whale liver, it is only about $17 \%$ of the total Se in pygmy 
sperm whale liver. Hence, a significant fraction of the Se is likely to be present in other forms in the case of the pygmy sperm whale. Such differences are confirmed by the Se XANES data shown in Figure 3.

For the beluga whale liver tissues in which the $\mathrm{Hg}$ content was $150 \mathrm{ppm}$ (lyophilized tissues) and the $\mathrm{Hg} / \mathrm{Se}$ molar ratio was $0.66, \mathrm{HgSe}$ was clearly present as indicated by both the $\mathrm{Hg}$ and the Se XAFS spectra. For the pygmy sperm whale liver tissues in which the Hg content is much lower (9 ppm in lyophilized tissues) and the $\mathrm{Hg} / \mathrm{Se}$ molar ratio was also much lower (0.17), the Hg XAFS spectrum was similar to that of the beluga whale, but the Se XAFS spectrum was much different, indicating that proportionately less Se was associated with $\mathrm{Hg}$ as $\mathrm{HgSe}$. Qualitatively, the $\mathrm{Hg}$ XAFS data indicate that $\mathrm{HgSe}$ is the major form of $\mathrm{Hg}$ in the beluga whale samples. Similarly, the data for $\mathrm{Hg}$ in the pygmy whale also indicates that much of the $\mathrm{Hg}$ in that whale's liver is present as $\mathrm{HgSe}$. While various prominent features of the Se XANES spectrum of $\mathrm{HgSe}$ are clearly apparent in the spectrum of the beluga whale liver, they are not obvious in the corresponding spectrum of the pygmy sperm whale liver. These differences are consistent with the mass concentration analytical data for $\mathrm{Hg}$ and $\mathrm{Se}$ in the two liver samples.

\section{Task 3 - Determination of Biochemical Threshold of MeHg Effects}

Since issues of concern regarding $\mathrm{MeHg}$ exposure arise from dietary intake of seafoods and $\mathrm{Se}$, it is important to study the physiologically relevant routes of $\mathrm{Hg}$ and Se uptake. The results of the current study coincide with observations from our other studies of $\mathrm{Se}-\mathrm{Hg}$ interactions in demonstrating that $\mathrm{Hg}$ risk assessments must also consider Se levels in food. The data support our hypothesis that dietary Se provides a potent protective effect against dietary $\mathrm{Hg}$

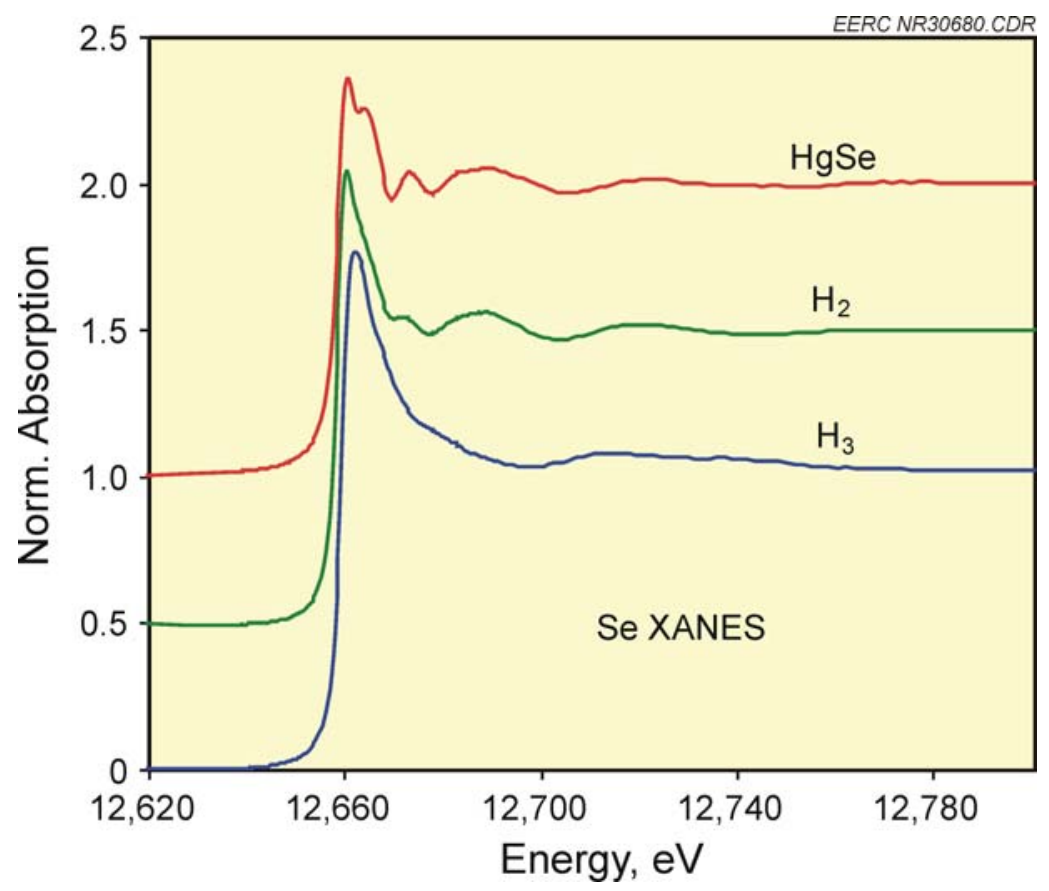

Figure 3. Se K-edge XANES data for HgSe and beluga (H2) and pygmy sperm whale (H3) liver. 
exposure. This study also indicates that levels of dietary Se that are slightly less than the average amounts present in commercial ocean fish are sufficient to prevent toxic effects from chronic exposure to $\mathrm{MeHg}$ from fish consumption. In fact, the study diets contained $\sim 100$ times more $\mathrm{MeHg}$ than is present in typical human diets that include seafood. Using data regarding food intakes and growth from a parallel study of $\mathrm{Hg}$ :Se interactions in rats, the single compartment model shown in Figure 4 was generated.

Establishing a single-compartment POINT model revealed that consuming diets containing low Se results in a steady diminishment of tissue Se concentrations. Once growth stabilizes, the Se contents in tissues of these rats gradually begin to increase. The rapid brain growth in the weanling rat provides a reasonable reflection of both the rate and magnitude of human brain growth that occurs during gestation. Rats fed low-Se, high-MeHg diets experience rapidly diminishing Se availability within the first 2 weeks of exposure, then plateau at a Se-deficit level. The impaired weight gains of rats fed low dietary Se would be expected to soon follow. This POINT model indicates the adequate Se group that was fed high $\mathrm{MeHg}$ retains near normal levels of Se bioavailability after 18 weeks on this diet. A trend line based on declining bioavailability of Se during the last 16 weeks of the study indicates that after 40 weeks, Se bioavailability in this group will have declined to $\sim 5 \%$ of normal. This corresponds to the time when groups fed these approximate amounts of Se and $\mathrm{MeHg}$ have been observed to show motor function defects. Among rats fed rich-Se diets, the influx of dietary Se is accompanied by a rapid rise in tissue Se that would be expected to be followed by a steady decline as excretion of Se and $\mathrm{MeHg}$ increase. The balance of dietary influx and excretory elimination eventually achieves a steady state, with Se bioavailability maintained at a greater abundance than is required for maintaining optimal Se status. This is also true in the absence of $\mathrm{MeHg}$ exposure; the steady

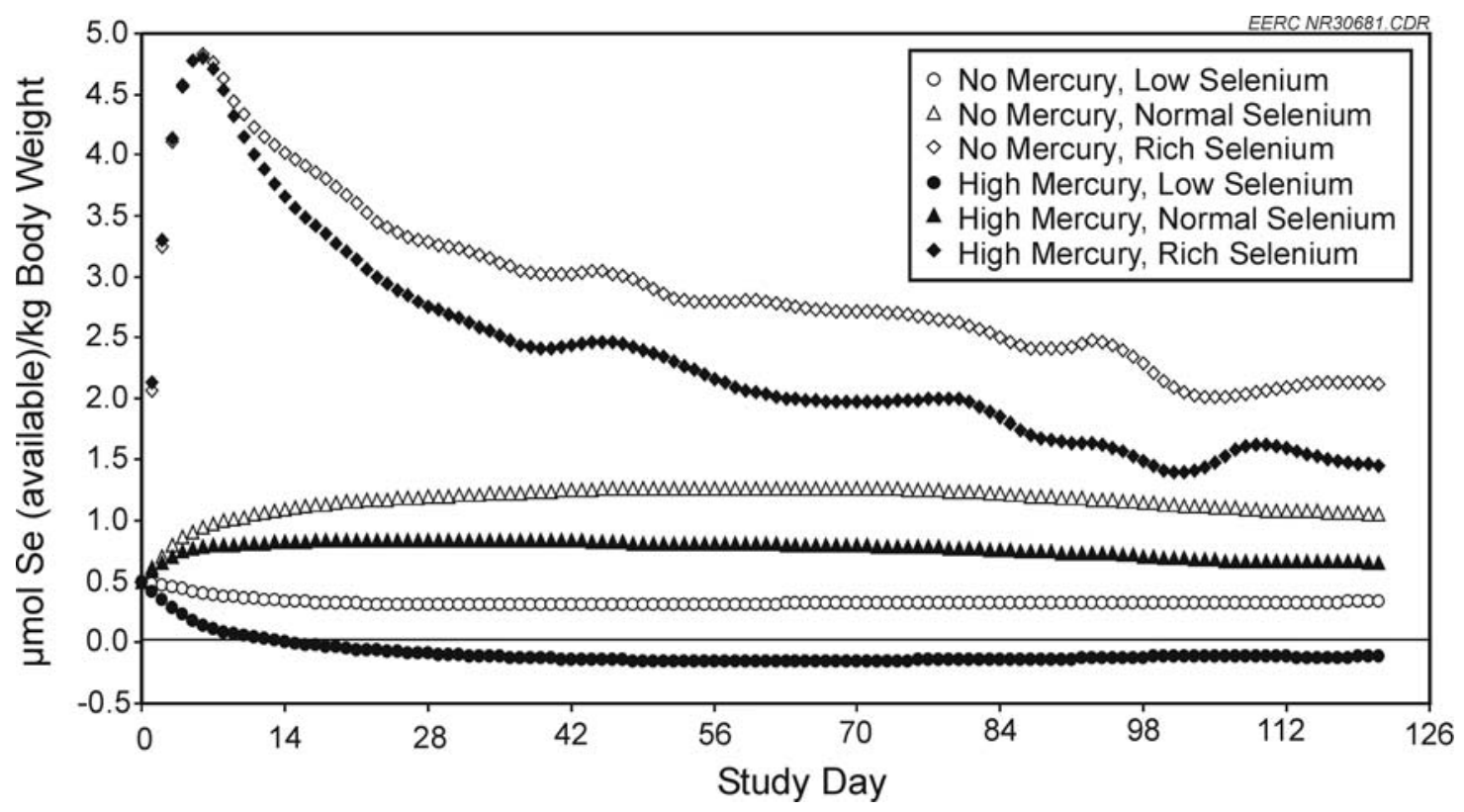

Figure 4. POINT models of dietary treatment effects on bioavailability of Se. 
state of bioavailable Se would, of course, be greater still. This model indicates that among animals fed a low Se diet with high $\mathrm{MeHg}$ exposure, even one day's consumption of a Se-rich diet $(10-\mu \mathrm{mol} \mathrm{Se} / \mathrm{kg}$ diet used in this version of the model) would be sufficient to bring internal bioavailability of Se back to a nearly normal range, regardless of whether $\mathrm{MeHg}$ is present (Figure 5). However, replenishing high-Se diets to Se-deficient animals in the actual study (see Task 96 final report) did not immediately restore their growth. This lag time may indicate normal anabolic processes and the sequential replenishment of Se in blood and tissue compartments.

The following slopes were created by plotting the growth impairments observed in the animal study against the $\mathrm{Hg}$, $\mathrm{Se}$, or $\mathrm{Hg}$ :Se ratios for tissues. The data were evaluated using regression statistics to establish the adjusted correlation coefficients $\left(r^{2}\right)$ and $p$ values for the relationships (Table 10). Since toxic effects were only seen in the rats exposed to the highest level of dietary $\mathrm{MeHg}$, only data from those groups are shown.

The most notable aspect of these analyses is that the slopes of tissue $\mathrm{Hg}$ concentrations relationships to toxicity were all negative and often significant $(\mathrm{p}<0.05)$. This occurred because increasing dietary Se resulted in increased tissue retention of $\mathrm{Hg}$ but diminished toxicity.

This is an extreme divergence from what would have otherwise been expected. These results do not imply that increasing tissue levels of $\mathrm{Hg}$ is healthy, just that tissue $\mathrm{Hg}$ levels alone do not provide a straightforward basis for evaluating risk. Tissue $\mathrm{Hg}$ levels were uniformly associated with dietary $\mathrm{MeHg}$ exposure in all the tissues studied. Importantly, since blood $\mathrm{Hg}$ was found to be inversely related to toxicity, the results of this study may have dramatic implications for human risk assessments that are based on analyses of blood $\mathrm{Hg}$ indices.

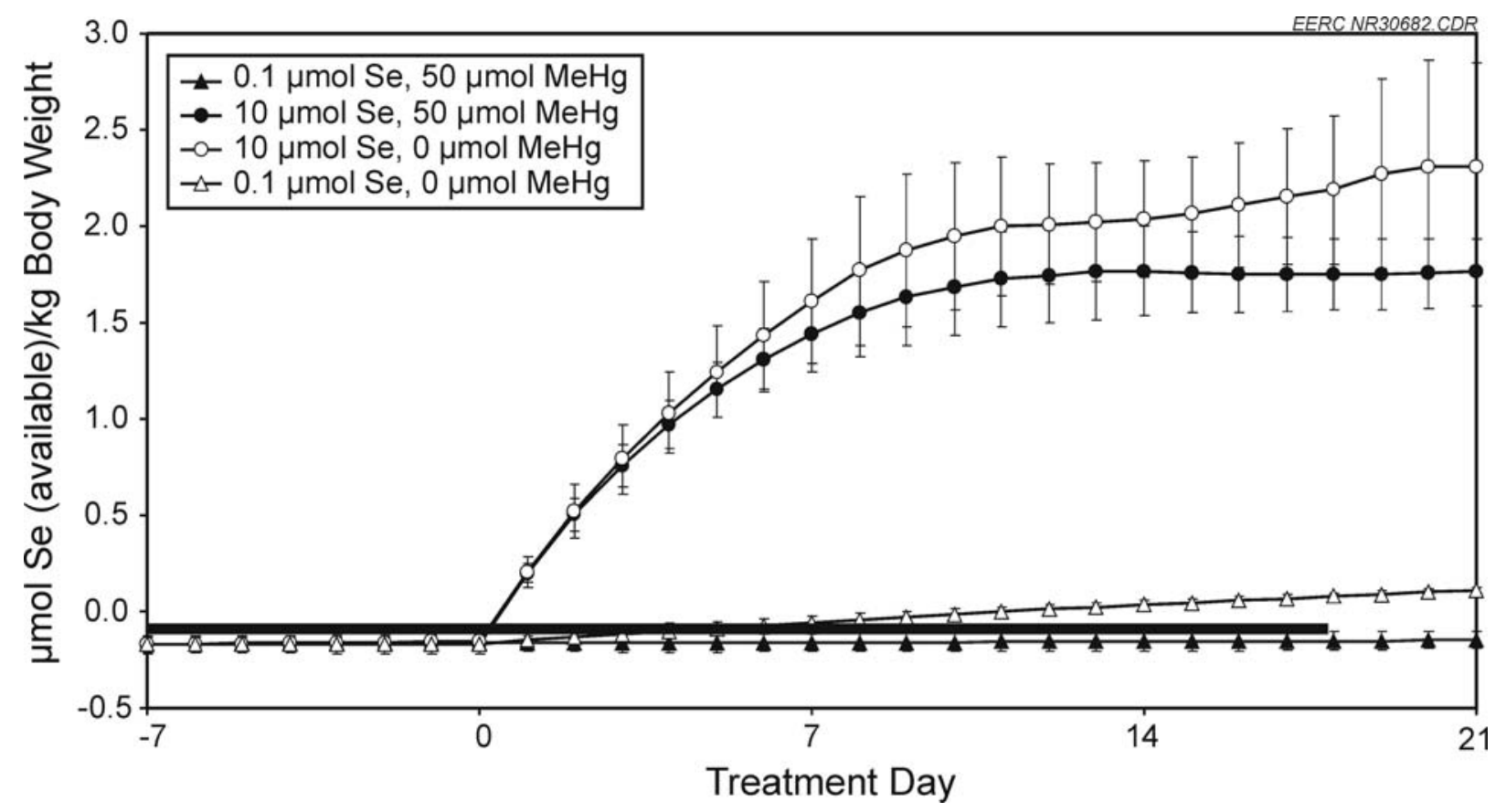

Figure 5. POINT model of effects of dietary treatment on Se bioavailability in rats. Graph depicts means \pm standard deviations of group data at the times indicated. 
Table 10. Correlations Between Indices and Observed Toxicity

\begin{tabular}{lccc}
\hline \multicolumn{1}{l}{ Tissue Hg Relationship to Relative Toxicity } & & \\
\hline Tissue & \multicolumn{1}{c}{ Slope } & Adjusted $\mathrm{r}^{2}$ & $\mathrm{p}$ Value \\
\hline Kidney & $\mathrm{y}=-0.0002 \mathrm{x}+0.3484$ & 0.14 & 0.038 \\
Liver & & & 0.18 \\
Testes & $\mathrm{y}=-0.0013 \mathrm{x}+0.3962$ & 0.14 & 0.04 \\
Brain & $\mathrm{y}=-0.0017 \mathrm{x}+0.3349$ & 0.10 & 0.08 \\
Pituitary & $\mathrm{y}=-0.0005 \mathrm{x}+0.279$ & 0.26 & 0.006 \\
Blood & $\mathrm{y}=-0.001 \mathrm{x}+0.4446$ & 0.24 & 0.009 \\
Toenails & & 0.63 \\
\hline Tissue Se Relationship to Relative Toxicity & Slope & Adjusted $\mathrm{r}^{2}$ & $\mathrm{p}$ Value \\
\hline Tissue & $\mathrm{y}=-0.0002 \mathrm{x}+0.1579$ & 0.16 & 0.028 \\
\hline Kidney & $\mathrm{y}=-0.0007 \mathrm{x}+0.1587$ & 0.18 & 0.023 \\
Liver & $\mathrm{y}=-0.0036 \mathrm{x}+0.3433$ & 0.15 & 0.036 \\
Testes & $\mathrm{y}=-0.005 \mathrm{x}+0.1691$ & 0.13 & 0.044 \\
Brain & $\mathrm{y}=-0.0017 \mathrm{x}+0.1829$ & 0.17 & 0.026 \\
Pituitary & $\mathrm{y}=-0.0147 \mathrm{x}+0.1975$ & 0.30 & 0.003 \\
Blood & $\mathrm{y}=-0.0139 \mathrm{x}+0.1859$ & 0.19 & 0.02 \\
Toenails & Slope & & $\mathrm{p}$ Value \\
\hline Tissue Hg:Se Relationship to Relative Toxicity & Adjusted $\mathrm{r}^{2}$ & 0.0001 \\
\hline Tissue & $\mathrm{y}=0.0024 \mathrm{x}+0.0412$ & 0.47 & 0.0002 \\
\hline Kidney & $\mathrm{y}=0.0011 \mathrm{x}+0.0562$ & 0.45 & 0.65 \\
Liver & & & 0.009 \\
Testes & $\mathrm{y}=0.0062 \mathrm{x}+5 \mathrm{E}-05$ & 0.24 & 0.12 \\
Brain & & & 0.0003 \\
Pituitary & $\mathrm{y}=0.0006 \mathrm{x}+0.0298$ & 0.43 & 0.002 \\
Blood & $\mathrm{y}=0.0001 \mathrm{x}+0.0224$ & 0.33 & \\
Toenails & & &
\end{tabular}

When the observed incidence of toxicity in relation to tissue Se is examined, a negative slope is also observed, indicating that increasing Se was associated with diminishing toxicity. These relationships were uniformly significant $(\mathrm{p}<0.05)$, and were often highly significant $(\mathrm{p}<$ $0.01)$. The correlation coefficients $\left(r^{2}\right)$ for the inverse relationship between tissue Se and toxicity were generally far stronger than those observed for the inverse relationship between tissue $\mathrm{Hg}$ and toxicity. As would be expected, tissue Se levels were uniformly associated with dietary Se intake in all tissues studied.

In Table 10, the slope of the relationship between $\mathrm{Hg}$ :Se ratios and toxicity are all positive, indicating that the more moles of $\mathrm{Hg}$ that were present relative to moles of Se in a tissue, the greater the risk of toxicity. The correlation coefficients for tissue Hg:Se are far stronger than for either of the other indices. Testes and pituitary were exceptions in that they appeared to be far better protected against Se loss than any of the other tissues and, as a result, displayed far less dramatic $\mathrm{Hg}: \mathrm{Se}$ ratios than the other tissues. 
Toenail, and blood $\mathrm{Hg}$ concentrations are primary indices of $\mathrm{MeHg}$ exposure that are currently used for evaluating human health risks. This study supports the correlation of these indices with exposure levels. However, distribution of $\mathrm{Hg}$ into toenail and blood compartments was also highly influenced by Se status. Using growth inhibition of rats exposed to $70 \mu$ mol $\mathrm{MeHg} / \mathrm{kg}$ as a measure of relative toxicity in these groups, the toxic effects and observed toenail and blood $\mathrm{Hg}$ concentrations were inversely related. In contrast to expectation, higher $\mathrm{Hg}$ contents in toenail and blood compartments were associated with diminishing toxicity. Lower toenail and blood $\mathrm{Hg}$ were observed in the low-Se rats that showed the greatest toxic effects, while rats fed Se-rich diets were least affected but had the highest Hg contents.

This study offers an explanation for the contradictory results reported in population studies. The largest and most thorough population study, currently proceeding in the United Kingdom, has found that increased maternal fish consumption was beneficial, but reductions in fish consumption during pregnancy was associated with diminished child performance. The plot of their blood $\mathrm{Hg}$ levels would therefore have a negative slope, similar to the results reported in this study. The added selenium supplied from increased fish consumption may therefore contribute to the health benefits of increased fish consumption in this population.

\section{CONCLUSIONS}

The goal of the EERC Health Effects Research Program is to improve the understanding of $\mathrm{Hg}-\mathrm{Se}$ binding interactions and their involvement in Se-dependent prevention of $\mathrm{MeHg}$ toxicity. Toward this goal, the primary objective of this project was to investigate the biochemical mechanism for dietary Se's protective effect against $\mathrm{Hg}$ toxicity using physiological levels of Se. The results from this project support the premise that rather than Se offering protection from $\mathrm{Hg}$ toxicity through $\mathrm{Hg}$ sequestration, $\mathrm{Hg}$ toxicity may occur as the result of $\mathrm{Se}$ sequestration, thereby inhibiting Se-dependent physiological processes in brain and related tissues. If this is indeed the case, it follows that the mechanism of Se-dependent protection against $\mathrm{Hg}$ toxicity is the result of supplemental Se replacing the intracellular Se lost to $\mathrm{Hg}$ sequestration, thus maintaining normal Se-dependent physiology in brain and endocrine tissues.

Supporting observations and conclusions from this project are summarized as follows:

- At toxic levels of dietary $\mathrm{MeHg}$ exposure Se retention was accentuated in blood and $\mathrm{Se}$ delivery to brain was diminished when dietary Se intakes were low, but brain Se increased when dietary Se was rich.

- Conversely, increasing dietary Se generally resulted in greater total $\mathrm{Hg}$ retention in kidney, liver, testes, pituitary, blood, and brain, possibly as $\mathrm{HgSe}$ conjugates.

- High MeHg exposures resulted in slightly increased Se retention in livers of rats fed low dietary Se, possibly diminishing the usual Se redistribution to other tissues.

- Accumulation of $\mathrm{Hg}$ in liver was directly proportional to dietary $\mathrm{MeHg}$ at each level of dietary Se but increased with increasing dietary Se intakes. 
- High MeHg exposure increased Se retention in kidneys of rats fed low dietary Se.

- Toenail and blood Hg levels accurately reflected exposure but did not correspond with development of signs and symptoms of $\mathrm{MeHg}$ toxicity.

- Among animals fed high-MeHg diets, increased Hg in toenails, blood, and brain was associated with decreased toxicity, a highly counterintuitive finding if $\mathrm{Hg}-\mathrm{Se}$ interaction effects are not understood.

- In this study, MeHg toxicity was apparent among rats fed Se-deficient diets.

- The increased molar excess of $\mathrm{Hg}$ :Se was a superior index of $\mathrm{Hg}$ toxicity.

- Typical varieties of ocean fish have a 5-20-fold molar excess of Se over MeHg content.

- The Se-rich diets $(7 \mu \mathrm{mol} \mathrm{Se} / \mathrm{kg})$ used in this study contained less Se than is usually present in typical varieties of commercial ocean fish $(\sim 10 \mu \mathrm{mol} \mathrm{Se} / \mathrm{kg})$ but protected against toxic effects of $\mathrm{MeHg}$ present at concentrations that are multiple log orders higher than those occurring in normal seafood diets.

- Low-level MeHg exposures that occur in typical varieties of ocean fish therefore appear unlikely to be harmful because Se is consistently in molar excess of their $\mathrm{MeHg}$ contents. However, this may not be true for freshwater fish since their Se levels can be more variable depending on the Se status of their lake of origin.

- Seafood safety criteria need to incorporate reporting Hg:Se molar ratios present in the fish to provide more meaningful risk evaluations for improving public health.

- To properly evaluate actual risks of maternal MeHg exposure, future studies will need to incorporate $\mathrm{Hg}: \mathrm{Se}$ molar ratios in blood as a primary risk index, rather than just measuring $\mathrm{MeHg}$ exposure, an index that is insufficient to provide interpretable results.

\section{REFERENCES}

Behne, D.; Gessner, H.; Kyriakopoulos, A. (1996) Information on the selenium status of several body compartments of rats from the selenium concentrations in blood fractions, hair and nails. J. Trace Elements in Medicine and Biology, vol. 10, no. 3, 174-179.

Behne, D.; Pfeifer, H.; Rothlein, D.; Kyriakopoulos, A. (2000) Cellular and subcellular distribution of selenium and selenium-containing proteins in the rat. In Trace Elements in Man and Animals 10, p. 29-34 [A.M. Roussel, A.E. Favier, and R.A. Anderson, editors]. New York: Kluwer Academic/Plenum Publishers.

Bosl, M.R.; Takaku, K.; Oshima, M.; Nishimura, S.; Taketo, M.M. (1997) Early embryonic lethality caused by targeted disruption of the mouse SeCys tRNA gene (Trsp). Proceedings of the National Academy of Sciences USA, vol. 94, 5531-5534. 
Burk, R.F.; Hill, K.E. (1993) Regulation of selenoproteins. Annual Review of Nutrition, vol. 13, $65-81$.

Byczkowski, J.Z. (2005) Methylmercury toxicity: Pharmacokinetics and toxicodynamic aspects. Reviews in Food and Nutrition Toxicity, vol. 3, 61-84.

Clewell, H.J.; Gearhart, J.M.; Gentry, P.R.; Covington, T.R.; Van Landingham, C.B.; Crump, K.S.; Shipp, A.M. (1999) Evaluation of the uncertainty in an oral reference dose for methylmercury due to interindividual variability in pharmacokinetics. Risk Anal. vol. 19, no. $4,547-558$.

Combs, G.F., Jr.; Lu, J. (2006) Selenium as a cancer preventive agent. In Selenium [DL Hatfield, Berry, Gladyshev, editors]. Its molecular biology and role in human health. New York, Springer Science+Business Media, LLC. p. 249-264.

Dyrssen, D.; Wedborg, M. (1991) The sulfur-mercury (II) system in natural waters. Water, Air \& Soil Pollution, no. 56, 507-519.

Gray, D.G. (1995) A physiologically based pharmacokinetic model for methylmercury in the pregnant rat and fetus. Toxicol. Appl. Pharmacol., vol. 132, no. 1, 91-102.

Hill, KE.; Zhou, J.; McMahan, W.J.; Motley, A.K.; Atkins, J.F.; Gesteland, R.F.; Burk, R.F. (2003) Deletion of selenoprotein P alters distribution of selenium in the mouse. Journal of Biological Chemistry, vol. 278, no. 16, 13640-13646.

Kaneko, M.; Natsuhori, M.; Ito, N.; Sera, K.; Futatsugawa, S. (1999) Tissue concentration-time profile of selenium after sodium selenite administration to rats. International Journal of PIXE, vol. 9, nos. 3 \& 4, 315-323.

Kirman, C.R.; Sweeney, L.M.; Meek, M.E.; Gargas, M.L. (2003) Assessing the dosedependency of allometric scaling performance using physiologically based pharmacokinetic modeling. Regul. Toxicol. Pharmacol., vol. 38, no. 3, 345-67.

Kohrle, J.; Brigelius-Flohe, R.; Bock, A.; Gartner, R.; Meyer, O.; Flohe, L. (2000) Selenium in biology: Facts and medical perspectives. Biology Chemistry, vol. 381, 849-864.

Ramauge, M.; Pallud, S.; Esfandiari, A.; Gavaret, J.M.; Lennon, A.M.; Pierre, M.; Courtin, F. (1996) Evidence that Type III iodothyronine deiodinase in rat astrocyte is a selenoprotein. Endocrinology, vol. 137, no. 7, 3021-3025.

Rayman, M. (2000) The importance of selenium to human health. Lancet, vol. 356, 233-241.

Reeves, P.G.; Leary, P.D.; Gregoire, B.R.; Finley, J.W.; Lindlauf, J.E.; Johnson, L.K., (2005) Selenium bioavailability from buckwheat bran in rats fed a modified AIN-93G torula yeastbased diet Journal of Nutrition, vol. 135, no. 11, 2627-2633. 
Roy, M.; Kiremidjian-Schumacher, L.; Wishe, H.I.; Cohen, M.W.; Stotzky, G. (1995) Supplementation with selenium restores age-related decline in immune cell function. Proceedings of the Society for Experimental Biology and Medicine, vol. 209 no. 4, 369375.

Shipp, A.M.; Gentry, P.R.; Lawrence, G.; Van Landingham, C.; Covington, T.; Clewell, H.J.; Gribben, K.; Crump, K. (2000) Determination of a site-specific reference dose for methylmercury for fish-eating populations. Toxicology and Industrial Health, vol. 16, nos. 9-10, 335-438.

Smith, J.C.; Farris, F.F. (1996) Methylmercury pharmacokinetics in man: A reevaluation. Toxicology and Applied Pharmacology, vol. 137 no. 2, 245-52.

Weiss, B.; Stern, S.; Cernichiari, E.; Gelein, R. (2005) Methylmercury contamination of laboratory animal diets. Environmental Health Perspectives, vol. 113, no. 9, 1120-1122.

Westermarck, T. (1977) Selenium content of tissues in Finnish infants and adults with various diseases and Studies on the effects of selenium supplementation in neuronal ceroid lipofuscinosis patients. Acta Pharmacologica et Toxicologica, vol. 41, no. 2, 121-8.

Whanger, P.D. (2001) Selenium and the brain: A review. Nutritional Neuroscience, vol. 4, no. 2, 81-97.

Young, J.F.; Wosilait, W.D.; Luecke, R.H. (2001) Analysis of methylmercury disposition in humans utilizing a PBPK model and animal pharmacokinetic data. Journal of Toxicology and Environmental Health. Part A, vol. 63, no. 1, 19-52.

Zachara, B.A.; Pawluk, H.; Bloch-Boguslawska, E.; Sliwka, K.M.; Korenkiewicz, J.; Skok, Z.; Ryc, K. (2001) Tissue level, distribution, and total body selenium content in healthy and diseased humans in Poland. Archives of Environmental Health, vol. 56, no. 5, 461-466. 